\title{
Therapeutic use of Fisetin and Fisetin Loaded on Mesoporous Carbon Nanoparticle (MCN) in Thioglycollate-induced Peritonitis
}

Shinjini Mitra', Silpak Biswas', Aryabaran Sinha², Nikhil Ranjan Jana² and Ena Ray Banerjee ${ }^{1 *}$

${ }^{1}$ Department of Zoology, Immunology and Regenerative Medicine Research Laboratory, University of Calcutta, 35, Ballygunge Circular Road, Kolkata-700019, West Bengal, India

${ }^{2}$ Centre for Advanced Materials, Indian Association for the Cultivation of Science, Jadavpur, Kolkata-700032, India

\begin{abstract}
Background: The pathophysiology of aseptic peritonitis involves inflammation of the serosal membrane that lines the abdominal cavity and the organs contained therein. The etiology of peritonitis is complicated and is involved in various processes, of which, the most important one is the inflammatory reaction. During the pathological process of peritonitis, NF-KB plays an activating role in the inflammatory reaction, which might be a potential therapeutic target in the therapy of certain inflammatory diseases. We studied the anti-inflammatory and pro-regenerative actions of Fisetin, a flavonol found in many plants, in a mouse model of thioglycollate-induced peritonitis, as well as the actions of fisetin administered with a nanoparticle such as mesoporous carbon nanoparticle (MCN). BALB/c mice were used in this study.

Results: We found cell recruitment in the blood increased with the administration of thioglycollate (TG) after $24 \mathrm{~h}$, $48 \mathrm{~h}, 72 \mathrm{~h}$ and $96 \mathrm{~h}$, showing that it has induced inflammation. Cell recruitment was successfully inhibited by fisetin, and with $\mathrm{MCN}+$ fisetin. In the peritoneal fluid, total cell recruitment was increased, which was successfully inhibited with fisetin and $\mathrm{MCN}+$ fisetin treatment. TG treatment significantly reduced cell proliferation in the blood, PF and BM, within $24 \mathrm{~h}$, till $96 \mathrm{~h}$. Interestingly, cell proliferation increased with fisetin treatment, and with $\mathrm{MCN}+$ fisetin. The clonogenic potential of the tissues decreased significantly within $24 \mathrm{~h}$, with administration of TG. Both fisetin treatment and MCN+fisetin treatment restored the clonogenic potential of the tissues. There was a decrease in Th2 cytokines with TG treatment, in blood after $48 \mathrm{~h}$, and both fisetin and $\mathrm{MCN}+$ fisetin increased the cytokine content.
\end{abstract}

Conclusion: In conclusion, we found that fisetin had a promising therapeutic effect on the peritonitis.

Keywords: Fisetin; Inflammation; Aseptic peritonitis; Mesoporous carbon nanoparticles; Inflammation; Anti-oxidant; Phenolic compounds; Scavenger activities; Reactive oxygen nitrogen intermediates

Abbreviations: TG: Thioglycollate; F: Only Fisetin; MF: Fisetin loaded on MCN; TG24, TG48, TG72, TG96: Treatment with only TG; sacrifice after 24 h, 48 h, 72 h, 96 h. TG24F, TG48F, TG72F, TG96F: Treatment with TG, followed by Fisetin; sacrifice after 24 h, 48 h, 72 h, 96 h; TG24MF, TG48MF, TG72MF, TG96MF: Treatment with TG, followed by MF; sacrifice after 24 h, 48 h, 72 h, 96 h; PB: Peripheral Blood sample; PF: Peritoneal Fluid sample; BM: Bone Marrow sample; TC: Total cell count; DC: Differential Cell Count; NO: Nitric Oxide; MTS: [3-(4, 5- dimethyl thiazol-2-yl)-5-(3-carboxy methoxy phenyl)2-(4-sulfophenyl)-2H-tetrazolium, inner salt]; PMS: Phenazine Methosulfate; CFU-c: Colony Forming Units in Culture; MPK: Milligram per Kilogram of Body Weight

\section{Symbols Used:}

\#: Denotes significance in samples with respect to control.

*: Denotes significance in samples with respect to samples treated with only TG.

*: Denotes significance in samples with respect to samples treated with TG-F.

\section{Background}

Peritonitis is the inflammation of the peritoneum, which was the thin tissue that lines the inner wall of the abdomen, and covers most of the abdominal organs. Infected peritonitis is caused by perforation of part of the gastrointestinal (GI) tract, by disruption of the peritoneum or by systemic infections. Local intra-abdominal focus of inflammation caused by the microorganisms can promote the synthesis and secretion of massive inflammatory cytokines, which would destroy the endothelial junctions and provide access for bacteria into the systemic circulation leading to lethal bacteremia [1,2]. A more severe inflammatory response process usually indicates a much higher mortality. The oxidative stress induced by the direct effect of bacteria and indirect effect of inflammation also contributes to the severity of peritonitis [3]. The microorganisms and their components can immediately activate the transcription factors-nuclear factor $-\kappa \mathrm{B}(\mathrm{NF}-\kappa \mathrm{B})$. NF- $\mathrm{NB}$ can initiate gene expression of cytokines, adhesion molecules, chemokines, and cytotoxic enzymes, which are considered to be directly responsible for the organ injury and death [4-8]. Non-infected peritonitis may be caused by leakage of sterile body fluids into the peritoneum, or by sterile abdominal surgery, which may inadvertently leave behind foreign bodies. In normal conditions, the peritoneum appears grayish and glistening; it becomes dull 2-4 hours after the onset of peritonitis, initially with scarce serous or slightly turbid fluid. Later on, the exudate becomes creamy and evidently suppurative. Although high-class antibiotics and advanced intensive care have proven to be

*Corresponding author: Ena Ray Banerjee, Associate Professor, Department of Zoology, Immunology and Regenerative Medicine Research Laboratory, University of Calcutta, 35, Ballygunge Circular Road, Kolkata-700019, West Bengal, India, Tel: 9163739975; Fax: 91-33-24614849; E-mail: enarb1@gmail.com

Received October 13, 2015; Accepted November 25, 2015; Published December 05, 2015

Citation: Mitra S, Biswas S, Sinha A, Jana NR, Banerjee ER (2015) Therapeutic use of Fisetin and Fisetin Loaded on Mesoporous Carbon Nanoparticle (MCN) in Thioglycollate-induced Peritonitis. J Nanomed Nanotechnol 6: 332 doi:10.4172/2157-7439.1000332

Copyright: (C) 2015 Mitra S, et al. This is an open-access article distributed under the terms of the Creative Commons Attribution License, which permits unrestricted use, distribution, and reproduction in any medium, provided the original author and source are credited. 
effective on the treatment, the morbidity and mortality remain kept at a high level $[9,10]$.

Inflammation is part of the complex biological response of vascular tissues to harmful stimuli, such as pathogens, damaged cells, or irritants $[11,12]$. It is a protective mechanism by the organism to eliminate injurious stimuli and to initiate the healing process. Inflammation is a mechanism of innate immunity $[13,14]$. Acute inflammation is the initial response of the body to harmful stimuli and is achieved by the increased movement of plasma and leukocytes from the blood into the injured tissues. Prolonged inflammation, known as chronic inflammation, leads to a progressive shift in the type of cells present at the site of inflammation and is characterized by simultaneous destruction and healing of the tissue from the inflammatory process. The process of acute inflammation is initiated by cells already present in all tissues, mainly resident macrophages, dendritic cells, histiocytes, Kupffer cells and mast cells. At the onset of an infection, these cells are activated and release inflammatory mediators, which are responsible for the clinical signs of inflammation [15]. Inflammation leads to increased production of reactive species like ROS (reactive oxygen species), NOS (nitric oxide synthase) and their product peroxynitrite $\left(\mathrm{ONO}_{2}^{-}\right)$by activated macrophages [16]. This increase in oxidative stress leads to decrease in effectiveness of oxidant defenses, that is, reduction in antioxidants.

Due to the various side effects and other complications of modern medicine, the use of traditional medicines and natural products is gaining popularity. Phytochemicals from fruits are being exploited as possible sources of therapeutic agents. Different biological activities of these chemicals, including their anti- oxidant properties and their antiinflammatory properties have been tested in vitro, as well as in vivo [17-19]. Nanomaterials, either as nanodrugs or as nano- vehicles, have the advantages of being small devices that are less invasive than normal medicines, that can be targeted to reach a particular site and that can possibly be implanted inside the body; also biochemical reaction times are much shorter. These devices are faster and more sensitive than typical drug delivery [20-22].

Mesoporous Carbon Nanoparticle (MCN) is a type of porous nanomaterial with a size of $100-200 \mathrm{~nm}$. It has several important properties such as high surface area, large pore volume, and a uniform pore size of $3 \mathrm{~nm}$. It is chemically inert, biocompatible and dispersible in water. Pores of MCN can be loaded with a large amount of drug molecules and then the drugs can be released by slow diffusion or other methods. These properties of the MCN make them useful for biomedical application [23-26].

The aim of our study was to test the anti- inflammatory and pro-regenerative actions of Fisetin, a flavonol found in many plants, including strawberries and apples, in a mouse model of thioglycollateinduced peritonitis. It protects against oxidative stress-induced cell death, by up-regulating expression of heme oxygenase $1\left(\mathrm{HO}^{-1}\right)$. We also aimed to test whether the anti- inflammatory and pro-regenerative actions of fisetin were enhanced when it was administered with a nanovehicle such as mesoporous carbon nanoparticle (MCN).

\section{Materials and Methods}

\section{Reagents and materials}

Sodium thioglycollate, Fetal Bovine Serum (FBS), RBC Lysis Buffer, Iscove's Modified Dulbecco's Media (IMDM), powdered Methyl Cellulose and Penicillin-Streptomycin were bought from Himedia, India. EDTA, methanol, Sulfanilamide and NED were bought from
Sisco Research Laboratory (SRL), India. DMEM from Gibco, Murine Stem Cell Factor (SCF) from Biovision, and Bovine Serum Albumin (BSA) from Biosera were used. Ortho-phosphoric acid and $\mathrm{NaNO}_{2}$ were purchased from Merck, India. 1X phosphate buffered saline (PBS) was prepared using $137 \mathrm{mM} \mathrm{NaCl}$ (Merck, India), $2.7 \mathrm{mM} \mathrm{KCl}$ (Himedia, India), $10 \mathrm{mM} \mathrm{Na}_{2} \mathrm{HPO}_{4}$ (Qualigens, India), $2 \mathrm{mM} \mathrm{KH}_{2} \mathrm{PO}_{4}$ (Himedia, India)

24 well plates and 96 well plates were obtained from Nest Biotech Co. Ltd., China. Dispovan syringes were used to obtain blood and peritoneal fluid. Smears for cell counting were prepared using Cytospin (Centurion Scientific $\mathrm{C}_{2}$ Series) after centrifuging the sample in a cold centrifuge (Vision VS-15000CFN). Smears were observed under a light microscope (Debro DX-200). Absorbance readings were taken in a multiplate reader (Thermo Fisher Multiskan EX). Plates were incubated in a $\mathrm{CO}_{2}$ incubator (Thermo Fisher), and colonies in CFU assay were observed using Floid Cell Imaging Station (Life Technologies, India). All cell-culture work was done inside the biosafety cabinet.

\section{Statistical analysis}

All data are presented as mean \pm SEM, and only $p$ values less than 0.05 have been considered as statistically significant. Statistical significance has been calculated using t- test in Graph Pad Prism 6.

\section{Animals}

$\mathrm{BALB} / \mathrm{c}$ mice were used in this study. All experiments were performed according to rules laid down by the Institutional and departmental animal ethics committee and the animals housed under specific pathogen-free conditions at the animal housing vivarium of the Department of Zoology, University of Calcutta.

\section{Ethics statement}

Animal ethical approval has been obtained by Institutional Bioethics Committee (dt 12-5-2010-Registration No. 885/ac/05/ CPCSEA)

\section{Induction of peritonitis}

$\mathrm{BALB} / \mathrm{c}$ mice (6-8 week old, weighing $25 \mathrm{gm}$ ) were divided into 13 groups $(\mathrm{n}=4)$ : Control, TG24, TG24F, TG24MF, TG48, TG48F, TG48MF, TG72, TG72F, TG72MF, TG96, TG96F, and TG96MF. 400 $\mu \mathrm{l}$ of $3 \% \mathrm{TG}$ was injected intra-peritoneally ( $200 \mu \mathrm{l}$ near each hind leg). The experiment was repeated twice.

\section{Treatment with fisetin and fisetin loaded onto MCN}

1 hour after treatment with TG, mice from four groups (TG24F, TG48F, TG72F and TG96F) were given $40 \mu \mathrm{l}$ of $2 \mu \mathrm{M} / \mathrm{kg}$ (0.57 MPK) fisetin orally. 1 hour after treatment with TG, mice from the other four groups (TG24MF, TG48MF, TG72MF and TG96MF) were treated with a mixture of fisetin and MCN. Equal amounts of $2 \mu \mathrm{M} / \mathrm{kg}$ fisetin was mixed with an equal amount of $5.1 \mathrm{mg} / \mathrm{ml} \mathrm{MCN}$, mixed well by vortexing, and administered intraperitoneally into the mice. Mice were sacrificed after 24 hours, 48 hours, 72 hours and 96 hours, and tissues were collected.

\section{Collection of samples}

Peripheral Blood (PB): Blood was collected by cardiac puncture, with $5 \mathrm{mM}$ EDTA to prevent clotting, in DMEM. For cell counting, blood was collected in RBC Lysis Buffer, kept at room temperature for 5 minutes, then flushed with $1 \mathrm{X}$ PBS, and centrifuged at $4000 \mathrm{rpm}$ for 5 minutes at $4^{\circ} \mathrm{C}$. The supernatant was discarded, and the pellet was 
dissolved in $1 \mathrm{X}$ PBS and stored at $4^{\circ} \mathrm{C}$.

Peritoneal Fluid (PF): $2 \mathrm{ml}$ of $1 \mathrm{X}$ PBS was slowly injected into the peritoneal cavity, and the cavity was massaged well to wash the cavity extensively. A $5 \mathrm{ml}$ syringe was inserted into the side of the mouse, and the plunger slowly pulled out to retrieve the maximal amount of peritoneal fluid. The PF was collected in DMEM medium.

Bone Marrow (BM): The bone of the hind leg of the mouse was taken into the biosafety cabinet, and flushed with DMEM till the bone turned white.

\section{Total and differential cell count (TC/DC)}

Differential white blood cell count is an examination and enumeration of the distribution of leukocytes in a stained blood smear. Increases in any of the normal leukocyte types or the presence of immature leukocytes or erythrocytes in peripheral blood are important diagnostically in a wide variety of inflammatory disorders.

The total number of cells and their viabilities were determined using a hemocytometer. Differential count was taken using a smear prepared in a cytospin. $100 \mu \mathrm{l}$ of each sample was loaded into the wells of a cytospin, and centrifuged at $2000 \mathrm{rpm}$ for 3 mins. The slides were removed, air dried and fixed with methanol. The smears are then stained with hematoxylin, counter- stained with Eosin, and observed under a microscope. The TC and the DC were plotted against each sample.

\section{Determination of nitric oxide content (NO Assay)}

Activation of immune system is associated with increase in macrophage NO production. Transient nature of NO makes it unsuitable for detection, but it is oxidized to Nitrite $\left(\mathrm{NO}_{2}^{-}\right)$and Nitrate $\left(\mathrm{NO}_{3}^{-}\right)$by nitrate reductase. The concentrations of these anions are used as quantitative measure of $\mathrm{NO}$ production using the Griess reaction. In this reaction, acidified $\mathrm{NO}_{2}$ produces a nitrosating agent, which reacts with sulfanillic acid to produce diazonium ion. This ion couples with NED (N-1-naphthyl ethylene diamine dihydrochloride) to form a coloured product that is measured spectrophotometrically at $540 \mathrm{~nm}$.

The reaction was standardized using different concentrations of $\mathrm{NaNO}_{2}(100 \mu \mathrm{M}, 50 \mu \mathrm{M}, 25 \mu \mathrm{M}, 12.5 \mu \mathrm{M}, 6.25 \mu \mathrm{M}, 3.13 \mu \mathrm{M}, 1.56$ $\mu \mathrm{M}$ and $0 \mu \mathrm{M}$ ), using the method in Promega User Guide (Product G2930). $50 \mu \mathrm{l}$ of cells from each sample (PB, PF and BM) from all the groups (Control, TG24, TG24F, TG24MF, TG48, TG48F, TG48MF, TG72, TG72F, TG72MF, TG96, TG96F, TG96MF) were plated in the wells of a 96-well plate. The cells were incubated for 24 hours, in a $\mathrm{CO}_{2}$ incubator at $5 \% \mathrm{CO}_{2}, 37^{\circ} \mathrm{C}$. Sulfanilamide solution was prepared by dissolving $1 \%$ Sulfanilamide in $5 \%$ ortho-phosphoric acid. $0.1 \%$ NED solution was prepared in distilled water. $50 \mu$ of sulfanilamide solution was added to each well, and incubated at room temperature for 5 minutes, in dark. $50 \mu$ of NED solution was then added, and incubated at room temperature for 5 minutes, in dark. Absorbance was measured in a plate reader at $540 \mathrm{~nm}$. Using the standard curve prepared, the absorbance values of the samples were plotted to get the concentrations of NO produced (in $\mu \mathrm{M}$ ). The concentrations of NO were plotted against each sample.

\section{Cell proliferation assay (MTS Assay)}

The MTS assay is a colourimetric method for determining the number of viable cells in culture. It uses solutions of a novel tetrazolium compound MTS [3-(4, 5-dimethyl thiazol-2-yl)-5-(3-carboxy methoxy phenyl)-2-(4-sulfophenyl)-2H-tetrazolium, inner salt] and an electron-coupling reagent PMS (Phenazine Methosulfate). MTS is bioreduced by cells into a formazan product that is soluble in tissue culture medium. Absorbance of formazan is measured at $492 \mathrm{~nm}$. The conversion of MTS to aqueous soluble formazan is accomplished by dehydrogenase enzymes found in metabolically active cells. Quantity of formazan product, as measured by the absorbance at $492 \mathrm{~nm}$, is directly proportional to the number of living cells in culture. The assay was performed using the Promega CellTiter $96^{\circ}$ AQueous NonRadioactive Cell Proliferation Assay Kit. $100 \mu$ of cells (PB, PF, and $\mathrm{BM})$ from all the samples were added to the wells of a 96-well plate, and incubated for 1 hour in a $\mathrm{CO}_{2}$ incubator at $5 \% \mathrm{CO}_{2}, 37^{\circ} \mathrm{C} .20 \mu \mathrm{l}$ of MTS/PMS solution was added to each well, and incubated in a $\mathrm{CO}_{2}$ incubator for 1-4 hours. Absorbance was measured immediately in a plate reader at $492 \mathrm{~nm}$.

The absorbance values for each sample were plotted against time. Taking absorbance of the control as $100 \%$ cell viability, the viabilities of the other samples were calculated. Fold changes in the viability of the samples were calculated.

\section{Determination of clonogenic potential of cells (CFU-c Assay)}

CFU-c (Colony Forming Units in culture) assay measures the clonogenic potential of cells. The assay is based on the ability of cells to proliferate and differentiate into colonies in a semi-solid medium, in response to cytokine stimulation. The colonies formed can be enumerated and characterised according to their unique morphology. Clonogenic potential is determined by dividing the number of colonies formed by the number of cells plated.

Number of cells per well taken was $1 \times 10^{6}$. For PF, $10^{5}$ cells were taken per well. CFU-c media was prepared using IMDM, supplemented with $30 \%$ FBS, 10\% BSA, 1\% Penicillin-Streptomycin and $5 \mathrm{ng} / \mathrm{ml}$ murine SCF. Lastly, $1.5 \%$ methylcellulose was added into the concoction. $1 \mathrm{ml} \mathrm{CFU-c}$ assay media and $500 \mu \mathrm{l}$ cell suspension was plated in each 24 well cell culture plate. The plates were kept in $\mathrm{CO}$ incubator at $5 \% \mathrm{CO}_{2}$ and $37^{\circ} \mathrm{C}$. All Colony types were counted after 7 days using Floid Cell Imaging Station, and pooled to get total CFU-c. A graph of Clonogenic Potential-vs-samples was plotted for each tissue sample.

\section{Cytokine analysis of peripheral blood}

The BD CBA Mouse Th1/Th2 Cytokine Kit (Catalog No. 551287) was used to measure Interleukin-2 (IL-2), Interleukin-4 (IL-4), Interleukin-5 (IL-5), Interferon- $\gamma$ (IFN- $\gamma)$ and Tumour Necrosis Factor (TNF) protein levels in peripheral blood samples. Bead array technology was used to simultaneously detect multiple cytokines in samples. Five bead populations with distinct fluorescent intensities are coated with capture antibodies, specific for the above-mentioned proteins. The beads are mixed to form the bead array, and resolved in a red channel of a flow cytometer. After addition of the samples to the sample assay tubes containing the capture beads, the Mouse Th1/Th2 PE Detection Reagent was added to each tube. The tubes were incubated for 1 hour at room temperature, in the dark, and then washed with 1 $\mathrm{ml}$ of wash buffer (centrifuge at $200 \mathrm{~g}$ for $5 \mathrm{mins}$ ). The supernatant is carefully discarded and $300 \mu \mathrm{l}$ of wash buffer added to resuspend the bead pellet.

\section{Results}

\section{TC of PB}

The TC of blood increased 1.94 fold $(\mathrm{p}<0.05)$ after $24 \mathrm{~h}, 2.21$ fold 
$(\mathrm{p}<0.05)$ after $48 \mathrm{~h}, 2.26$ fold $(\mathrm{p}<0.05)$ after $72 \mathrm{~h}$ and 2.51 fold $(\mathrm{p}<0.05)$ after $96 \mathrm{~h}$, on treatment with TG, as compared to untreated control groups. With fisetin treatment, the TC decreased 1.06 fold after $24 \mathrm{~h}$, 1.14 fold after $48 \mathrm{~h}, 1.17$ fold after $72 \mathrm{~h}$ and 1.24 fold $(\mathrm{p}<0.05)$ after $96 \mathrm{~h}$, compared to only TG. With MCN+fisetin treatment, the TC decreased 1.24 fold after $24 \mathrm{~h}, 1.56$ fold $(\mathrm{p}<0.05)$ after $48 \mathrm{~h}$, and 1.20 fold after $72 \mathrm{~h}$, but increased 1.26 fold $(\mathrm{p}<0.05)$ after $96 \mathrm{~h}$ compared to only TG. Compared to only fisetin, MCN has led to a decrease in TC after $24 \mathrm{~h}$ (1.17 fold), after $48 \mathrm{~h}$ (1.37 fold) and after $72 \mathrm{~h}$ (1.03 fold), but to an increase after $96 \mathrm{~h}$ ( 1.56 fold; $\mathrm{p}<0.05)$. This shows that cell recruitment increased in response to the inflammatory stimulus, as TG induces a systemic inflammation. Fisetin inhibits cell recruitment within $24 \mathrm{~h}$, as does MCN+fisetin. Inhibition is better with $\mathrm{MCN}$ till $72 \mathrm{~h}$, but there is no inhibition with MCN at $96 \mathrm{~h}$ (Table 1 and Figure 1).

\section{TC of PF}

The TC of PF increased 1.40 fold after $24 \mathrm{~h}, 1.47$ fold $(\mathrm{p}<0.05)$ after $48 \mathrm{~h}, 1.60$ fold after $72 \mathrm{~h}$ and 1.77 fold $(\mathrm{p}<0.05)$ after $96 \mathrm{~h}$, on treatment with TG, as compared to untreated control groups. With fisetin treatment, the TC decreased 1.02 fold after $24 \mathrm{~h}, 1.07$ fold after $48 \mathrm{~h}$, 1.05 fold after $72 \mathrm{~h}$, and 2.13 fold $(\mathrm{p}<0.05)$ after $96 \mathrm{~h}$, compared to only TG. With MCN+fisetin treatment, the TC decreased 1.17 fold after 24 $\mathrm{h}, 1.40$ fold $(\mathrm{p}<0.05)$ after $48 \mathrm{~h}, 1.07$ fold after $72 \mathrm{~h}$, and 1.36 fold after $96 \mathrm{~h}$, compared to only TG. Compared to only fisetin, MCN has led to

\begin{tabular}{|c|c|c|c|c|}
\hline PB & Total Cell Count $(\mathbf{x ~ 1 0} / \mathbf{m l}) \pm$ SEM & \multicolumn{3}{|c|}{ Fold change, with respect to } \\
\hline & & Control & TG & TG-F \\
\hline Control & $0.53 \pm 0.03$ & & & \\
\hline TG24 & $1.03 \pm 0.03$ & $(+) 1.94^{*}$ & & \\
\hline TG24F & $0.97 \pm 0.03$ & & $(-) 1.06$ & \\
\hline TG24MF & $0.83 \pm 0.09$ & & $(-) 1.24$ & $(-) 1.17$ \\
\hline TG48 & $1.17 \pm 0.09$ & $(+) 2.21^{*}$ & & \\
\hline TG48F & $1.03 \pm 0.09$ & & $(-) 1.14$ & \\
\hline TG48MF & $0.75 \pm 0.05$ & & $(-) 1.56^{*}$ & $(-) 1.37$ \\
\hline TG72 & $1.20 \pm 0.12$ & $(+) 2.26^{*}$ & & \\
\hline TG72F & $1.03 \pm 0.03$ & & $(-) 1.17$ & \\
\hline TG72MF & $1.00 \pm 0.06$ & & $(-) 1.20$ & $(-) 1.03$ \\
\hline TG96 & $1.33 \pm 0.09$ & $(+) 2.51^{\#}$ & & \\
\hline TG96F & $1.07 \pm 0.03$ & & $(-) 1.24^{*}$ & \\
\hline TG96MF & $1.67 \pm 0.09$ & & $(+) 1.26^{*}$ & $(+) 1.56^{*}$ \\
\hline
\end{tabular}

(": $p<0.05$ versus Control; *: $p<0.05$ versus TG; *: $p<0.05$ versus TG-F)

Table 1: Total cell count of blood samples, taken by hemocytometry. There is a 1.24 fold decrease $(p<0.05)$ with fisetin treatment after $96 \mathrm{~h}$, and a 1.56 fold decrease $(p<0.05)$ with $\mathrm{MCN}+$ fisetin treatment after $48 \mathrm{~h}$.

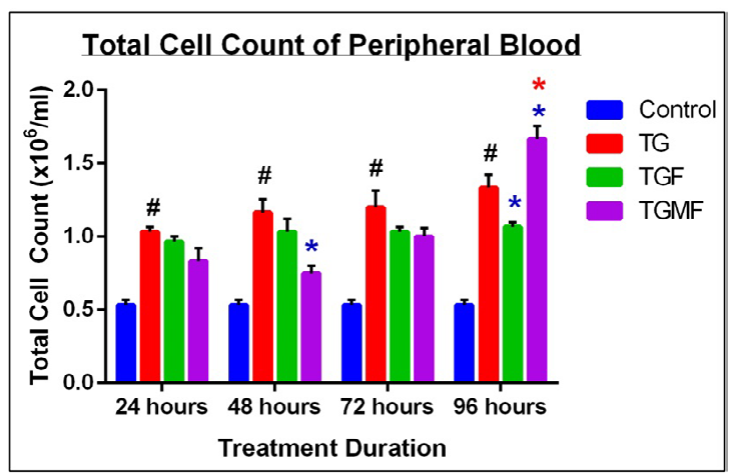

Figure 1: Effect of fisetin and $\mathrm{MCN}+$ fisetin on total cell count of peripheral blood (*: $p<0.05$ versus Control; *: $p<0.05$ versus TG; *: $p<0.05$ versus TG-F).

\begin{tabular}{|c|c|c|c|c|}
\hline & Total Cell Count $(\mathbf{x} \mathbf{1 0} / \mathbf{m l}) \mathbf{\pm}$ SEM & \multicolumn{3}{|l|}{ Fold change, with respect to } \\
\hline & & Control & TG & TG-F \\
\hline Control & $1.00 \pm 0.06$ & & & \\
\hline TG24 & $1.40 \pm 0.15$ & $(+) 1.40$ & & \\
\hline TG24F & $1.37 \pm 0.03$ & & $(-) 1.02$ & \\
\hline TG24MF & $1.20 \pm 0.12$ & & $(-) 1.17$ & $(-) 1.14$ \\
\hline TG48 & $1.47 \pm 0.03$ & $(+) 1.47^{\#}$ & & \\
\hline TG48F & $1.37 \pm 0.03$ & & $(-) 1.07$ & \\
\hline TG48MF & $1.05 \pm 0.05$ & & $(-) 1.40^{*}$ & $(-) 1.30^{*}$ \\
\hline TG72 & $1.60 \pm 0.32$ & $(+) 1.60$ & & \\
\hline TG72F & $1.53 \pm 0.03$ & & $(-) 1.05$ & \\
\hline TG72MF & $1.50 \pm 0.18$ & $(+) 1.77^{\#}$ & & \\
\hline TG96 & $1.77 \pm 0.15$ & & $(-) 2.13^{*}$ & \\
\hline TG96F & $0.83 \pm 0.12$ & & $(-) 1.36$ & $(+) 1.57^{*}$ \\
\hline TG96MF & $1.30 \pm 0.12$ & $(-) 1.02$ \\
\hline
\end{tabular}

(\#: $p<0.05$ versus Control; *: $p<0.05$ versus TG; *: $p<0.05$ versus TG-F)

Table 2: Total cell count of peritoneal fluid samples, taken by hemocytometry. There is a 2.13 fold $(p<0.05)$ decrease with fisetin treatment after $96 \mathrm{~h}$, and a 1.40 fold $(p<0.05)$ decrease with $M C N+$ fisetin after $48 \mathrm{~h}$.

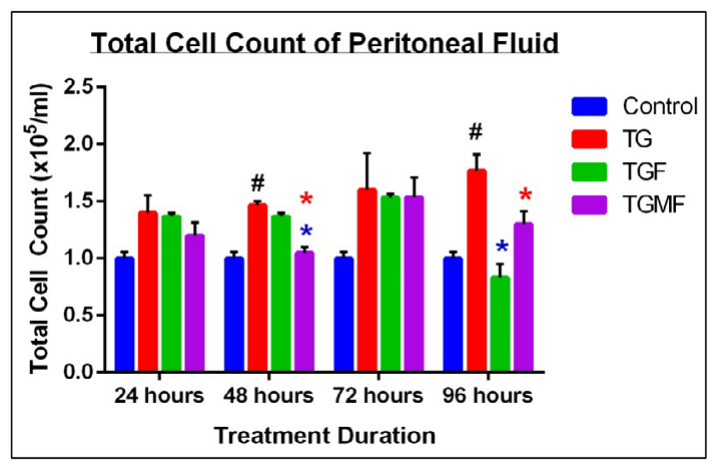

Figure 2: Effect of fisetin and $\mathrm{MCN}+$ fisetin on total cell count of peritoneal fluid (": $p<0.05$ versus Control; * $p<0.05$ versus TG; *: $p<0.05$ versus TG-F).

a decrease in TC after $24 \mathrm{~h}$ (1.14 fold), $48 \mathrm{~h}$ ( 1.30 fold; $\mathrm{p}<0.05)$ and $72 \mathrm{~h}$ ( 1.02 fold), but to an increase after $96 \mathrm{~h}$ ( 1.57 fold; $\mathrm{p}<0.05)$. Compared to only fisetin, MCN has led to a decrease in TC after $24 \mathrm{~h}$ (1.17 fold), after $48 \mathrm{~h}$ (1.37 fold) and after $72 \mathrm{~h}$ (1.03 fold), but to an increase after $96 \mathrm{~h}$ ( 1.56 fold; $\mathrm{p}<0.05)$. This shows that cell recruitment increases within $24 \mathrm{~h}$ in response to the inflammatory stimulus, as TG induces a systemic inflammation, and immune cells localize to the PF. Fisetin successfully inhibits cell recruitment within $24 \mathrm{~h}$, as does $\mathrm{MCN}+$ fisetin. Inhibition is better with MCN till $72 \mathrm{~h}$, but there is no inhibition with $\mathrm{MCN}$ at $96 \mathrm{~h}$ (Table 2 and Figure 2).

DC of neutrophils in PB: The count of polymorphonuclear (PMN) cells in the blood- eosinophils, basophils and neutrophils, increased (data not given) with TG. The numbers of neutrophils in the blood were found to have increased. There is a 1.10 fold increase after $24 \mathrm{~h}$, 1.66 fold $(\mathrm{p}<0.05)$ increase after $48 \mathrm{~h}, 2.39$ fold increase after $72 \mathrm{~h}$ and a 2.50 fold $(\mathrm{p}<0.05)$ increase after $96 \mathrm{~h}$ of TG treatment, compared to control. Neutrophil count decreased with fisetin after $72 \mathrm{~h}$ (1.12 fold) and $96 \mathrm{~h}$ ( 2.15 fold; $\mathrm{p}<0.05)$, and with $\mathrm{MCN}+$ fisetin after $48 \mathrm{~h}(1.17$ fold), $72 \mathrm{~h}$ ( 1.02 fold) and after $96 \mathrm{~h}$ ( 1.37 fold). Inhibition of neutrophil infiltration has been enhanced only at $48 \mathrm{~h}$ ( 1.35 fold; $\mathrm{p}<0.05)$ (Table 3 and Figure 3).

DC of lymphocytes in PB: The count of mononuclear (MN) cells 
Citation: Mitra S, Biswas S, Sinha A, Jana NR, Banerjee ER (2015) Therapeutic use of Fisetin and Fisetin Loaded on Mesoporous Carbon Nanoparticle (MCN) in Thioglycollate-induced Peritonitis. J Nanomed Nanotechnol 6: 332. doi:10.4172/2157-7439.1000332

Page 5 of 12

\begin{tabular}{|c|c|c|c|c|}
\hline Treatment & No. of neutrophils $\left(\mathbf{x} 1 \mathbf{0}^{\mathbf{5}}\right) / \mathbf{m l} \pm \mathbf{S E M}$ & \multicolumn{3}{|c|}{ Fold change, with respect to } \\
\hline & & Control & TG & TG-F \\
\hline Control & $3.22 \pm 0.16$ & & & \\
\hline TG24 & $3.53 \pm 0.32$ & $(+) 1.10$ & & \\
\hline TG24F & $3.70 \pm 0.73$ & & $(+) 1.05$ & \\
\hline TG24MF & $4.78 \pm 0.51$ & & $(+) 1.35$ & $(+) 1.29$ \\
\hline TG48 & $5.35 \pm 0.18$ & $(+) 1.66^{*}$ & & \\
\hline TG48F & $6.20 \pm 0.30$ & & $(+) 1.16$ & \\
\hline TG48MF & $4.58 \pm 0.34$ & & $(-) 1.17$ & $(-) 1.35^{*}$ \\
\hline TG72 & $7.70 \pm 1.85$ & $(+) 2.39$ & & \\
\hline TG72F & $6.88 \pm 0.25$ & & $(-) 1.12$ & \\
\hline TG72MF & $7.57 \pm 1.12$ & & $(-) 1.02$ & $(+) 1.10$ \\
\hline TG96 & $8.06 \pm 0.72$ & $(+) 2.50^{*}$ & & \\
\hline TG96F & $3.75 \pm 0.55$ & & $(-) 2.15^{*}$ & \\
\hline TG96MF & $5.88 \pm 0.60$ & & $(-) 1.37$ & $(+) 1.57^{*}$ \\
\hline
\end{tabular}

$\left({ }^{*}: p<0.05\right.$ versus Control; *: $p<0.05$ versus TG; *: $p<0.05$ versus TG-F)

Table 3: Differential count of neutrophils in peripheral blood, seen after HE staining, under light microscope. There is a 2.15 fold $(p<0.05)$ decrease with fisetin after 96 $\mathrm{h}$, and a 1.35 fold $(\mathrm{p}<0.05)$ decrease with $\mathrm{MCN}+$ fisetin after $48 \mathrm{~h}$.

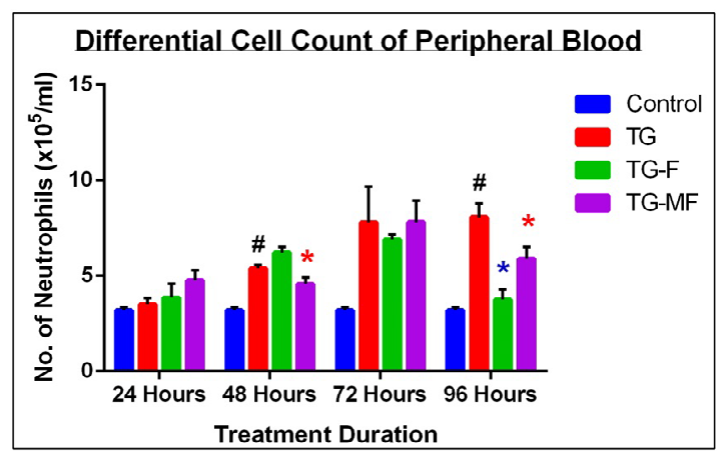

Figure 3: Effect of fisetin and MCN+fisetin on differential count of neutrophils of peripheral blood (\#: $p<0.05$ versus Control; *: $p<0.05$ versus TG; *: $p<0.05$ versus TG-F).

in the blood- lymphocytes and monocytes, increased (data not given) after TG treatment. The numbers of circulating lymphocytes have increased with TG treatment. There is a 1.53 fold increase after $24 \mathrm{~h}$, 1.54 fold $(\mathrm{p}<0.05)$ increase after $48 \mathrm{~h}, 1.57$ fold increase after $72 \mathrm{~h}$ and a 1.60 fold $(\mathrm{p}<0.05)$ increase after $96 \mathrm{~h}$ of TG treatment, compared to control. Lymphocyte count decreased with fisetin after $24 \mathrm{~h}(1.75$ fold; $\mathrm{p}<0.05), 48 \mathrm{~h}$ (1.30 fold; $\mathrm{p}<0.05), 72 \mathrm{~h}$ (1.18 fold) and $96 \mathrm{~h}(2.07$ fold; $\mathrm{p}<0.05)$, and with $\mathrm{MCN}+$ fisetin after $24 \mathrm{~h}$ (1.65 fold; $\mathrm{p}<0.05), 48$ $\mathrm{h}$ ( 1.70 fold; $\mathrm{p}<0.05), 72 \mathrm{~h}$ ( 1.18 fold) and after $96 \mathrm{~h}$ ( 1.30 fold; $\mathrm{p}<0.05)$. Inhibition of lymphocyte infiltration has been enhanced only at $48 \mathrm{~h}$ $(1.31$ fold; $\mathrm{p}<0.05)$ and at $72 \mathrm{~h}(1.01$ fold $)$ (Table 4 and Figure 4$)$.

\section{NO estimation of $P B$}

The NO concentration of peripheral blood shows a 1.03 fold increase after $24 \mathrm{~h}$, a 1.07 fold increase after $48 \mathrm{~h}$, a 1.12 fold increase after $72 \mathrm{~h}$ and a 1.23 fold increase after $96 \mathrm{~h}$, with TG, as compared to control. Administration of fisetin alone shows a 1.22 fold decrease after $24 \mathrm{~h}$, a 1.29 fold increase after $48 \mathrm{~h}$, a 1.06 fold increase after $72 \mathrm{~h}$, and a 3.21 fold decrease after $96 \mathrm{~h}$, compared to only TG. With MCN+fisetin, the NO concentration decreased 2.10 fold $(\mathrm{p}<0.05)$ after $24 \mathrm{~h}$ and 1.18 fold $(\mathrm{p}<0.05)$ after $96 \mathrm{~h}$, but increased 1.07 fold after $48 \mathrm{~h}$ and 1.44 fold after $72 \mathrm{~h}$, compared to only TG. Compared to fisetin, MCN has reduced the NO concentration 1.72 fold after $24 \mathrm{~h}$ and 1.20 fold after $48 \mathrm{~h}$ (Table 5 and Figure 5).

\begin{tabular}{|c|c|c|c|c|}
\hline \multirow{2}{*}{ Treatment } & No. of neutrophils $\left(\mathbf{x} 10^{5}\right) / \mathbf{m l} \pm \mathbf{S E M}$ & \multicolumn{3}{|c|}{ Fold change, with respect to } \\
\hline Control & & Control & TG & TG-F \\
\hline TG24 & $4.15 \pm 0.56$ & & & \\
\hline TG24F & $6.35 \pm 0.76$ & $(+) 1.53$ & & \\
\hline TG24MF & $3.63 \pm 0.60$ & & $(-) 1.75^{*}$ & \\
\hline TG48 & $3.86 \pm 0.33$ & $(+) 1.54^{\#}$ & & \\
\hline TG48F & $6.40 \pm 0.12$ & & $(-) 1.30^{*}$ & \\
\hline TG48MF & $4.94 \pm 0.06$ & & $(-) 1.70^{*}$ & $(-) 1.31^{*}$ \\
\hline TG72 & $3.77 \pm 0.28$ & $(+) 1.57$ & & \\
\hline TG72F & $6.52 \pm 1.09$ & & $(-) 1.18$ & \\
\hline TG72MF & $5.54 \pm 0.23$ & & $(-) 1.18$ & $(-) 1.01$ \\
\hline TG96 & $5.51 \pm 0.58$ & $(+) 1.60^{*}$ & & \\
\hline TG96F & $6.64 \pm 0.44$ & & $(-) 2.07^{*}$ & \\
\hline TG96MF & $3.21 \pm 0.53$ & & $(-) 1.30^{*}$ & $(+) 1.59^{*}$ \\
\hline
\end{tabular}

(": $p<0.05$ versus Control; * $p<0.05$ versus TG; *: $p<0.05$ versus TG-F)

Table 4: Differential count of lymphocytes in peripheral blood, seen after HE staining, under light microscope. Lymphocyte count decreased with fisetin, after 24 $\mathrm{h}(1.75$ fold; $p<0.05), 48 \mathrm{~h}$ (1.30 fold; $\mathrm{p}<0.05), 72 \mathrm{~h}$ and $96 \mathrm{~h}(2.07$ fold; $\mathrm{p}<0.05)$, and with MCN+fisetin, after $48 \mathrm{~h}(1.31$ fold; $\mathrm{p}<0.05)$ and $72 \mathrm{~h}(1.01$ fold $)$.

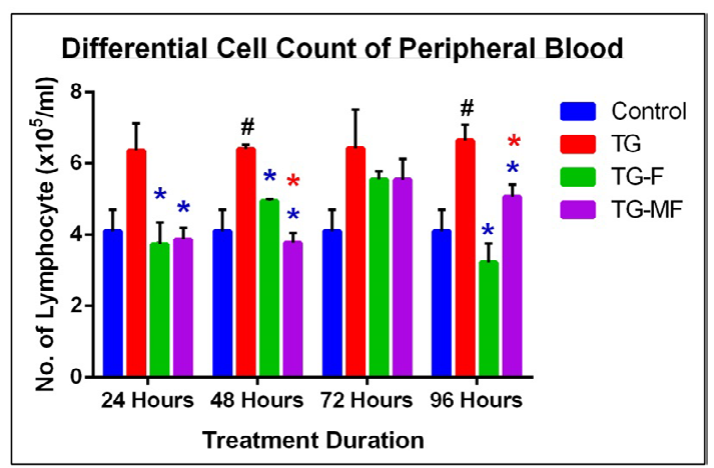

Figure 4: Effect of fisetin and $\mathrm{MCN}+$ fisetin on differential count of $\mathrm{MN}$ cells of peripheral blood (\#: $p<0.05$ versus Control; * $p<0.05$ versus TG; *: $p<0.05$ versus TG-F).

\begin{tabular}{|c|c|c|c|c|}
\hline & PB & Concentration of $\mathbf{N O}(\boldsymbol{\mu M}) \pm$ SEM & \multicolumn{3}{l|}{ Fold change, with respect to } \\
\hline Control & & Control & TG & TG-F \\
\hline TG24 & $29.59 \pm 1.34$ & & & \\
\hline TG24F & $30.61 \pm 1.70$ & $(+) 1.03$ & & \\
\hline TG24MF & $25.01 \pm 4.39$ & & $(-) 1.22$ & \\
\hline TG48 & $14.56 \pm 2.73$ & & $(-) 2.10^{*}$ & $(-) 1.72$ \\
\hline TG48F & $31.76 \pm 0.47$ & $(+) 1.07$ & & \\
\hline TG48MF & $40.95 \pm 22.18$ & & $(+) 1.29$ & \\
\hline TG72 & $34.10 \pm 15.77$ & & $(+) 1.07$ & $(-) 1.20$ \\
\hline TG72F & $33.16 \pm 2.12$ & $(+) 1.12$ & & \\
\hline TG72MF & $35.05 \pm 9.09$ & & $(+) 1.06$ & \\
\hline TG96 & $47.79 \pm 6.04$ & & $(+) 1.44$ & $(+) 1.36$ \\
\hline TG96F & $36.26 \pm 3.15$ & $(+) 1.23$ & & \\
\hline TG96MF & $11.29 \pm 1.29$ & & $(-) 3.21$ & \\
\hline
\end{tabular}

(*: $p<0.05$ versus Control; *: $p<0.05$ versus TG; * $p<0.05$ versus TG-F)

Table 5: Concentration and fold changes in nitric oxide produced in peripheral blood, assayed by Griess Reagent, at $540 \mathrm{~nm}$. With fisetin, there is a 1.22 fold decrease after $24 \mathrm{~h}$, and a 3.21 fold decrease after $96 \mathrm{~h}$. With MCN+fisetin, there is a 2.10 fold $(p<0.05)$ decrease after $24 \mathrm{~h}$ and a 1.18 fold $(p<0.05)$ decrease after $96 \mathrm{~h}$. 


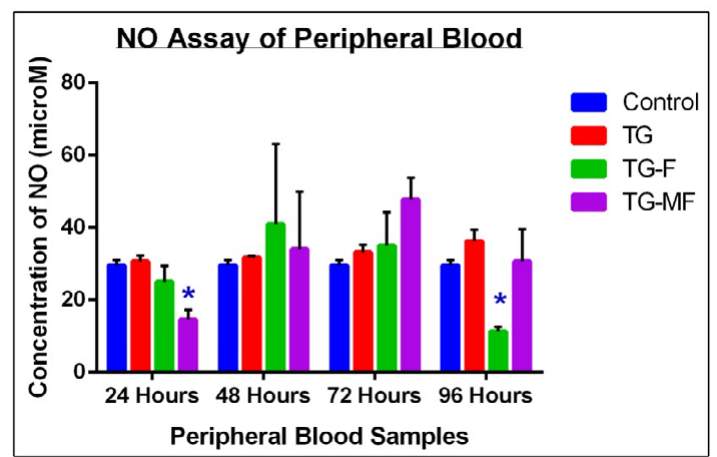

Figure 5: Effect of fisetin and $\mathrm{MCN}+$ fisetin on the production of nitric oxide in the blood (\#: $p<0.05$ versus Control; *: $p<0.05$ versus TG; *: $p<0.05$ versus TG-F).

\begin{tabular}{|c|c|c|c|c|}
\hline & PF & Concentration of NO $(\boldsymbol{\mu M}) \pm \mathbf{S E M}$ & \multicolumn{3}{|l|}{ Fold change, with respect to } \\
\hline Control & & Control & TG & TG-F \\
\hline TG24 & $5.04 \pm 1.21$ & & & \\
\hline TG24F & $11.97 \pm 1.56$ & $(+) 2.38^{\#}$ & & \\
\hline TG24MF & $9.29 \pm 1.38$ & & $(-) 1.29$ & \\
\hline TG48 & $10.84 \pm 5.20$ & & $(-) 1.10$ & $(+) 1.17$ \\
\hline TG48F & $13.03 \pm 2.13$ & $(+) 2.59$ & & \\
\hline TG48MF & $10.36 \pm 4.28$ & & $(-) 1.26$ & \\
\hline TG72 & $8.69 \pm 2.64$ & & $(-) 1.50$ & $(-) 1.19$ \\
\hline TG72F & $22.54 \pm 9.29$ & $(+) 4.47^{\#}$ & & \\
\hline TG72MF & $19.42 \pm 2.31$ & & $(-) 1.16$ & \\
\hline TG96 & $20.00 \pm 3.31$ & $(+) 4.89^{\#}$ & & \\
\hline TG96F & $24.67 \pm 1.59$ & & $(-) 1.88$ & \\
\hline TG96MF & $13.10 \pm 4.38$ & & $(-) 1.49$ & $(+) 1.27$ \\
\hline
\end{tabular}

(\#: $p<0.05$ versus Control; *: $p<0.05$ versus TG; *: $p<0.05$ versus TG-F)

Table 6: Concentration and fold changes in nitric oxide produced in peritoneal fluid, assayed by Griess Reagent, at $540 \mathrm{~nm}$. With fisetin, there is a 1.29 fold decrease after $24 \mathrm{~h}$, a 1.26 fold decrease after $48 \mathrm{~h}$, a 1.16 fold decrease after $72 \mathrm{~h}$ and a 1.88 fold decrease after $96 \mathrm{~h}$. With MCN+fisetin, there is a 1.19 fold decrease after $48 \mathrm{~h}$.

\section{NO estimation of PF}

The NO concentration of peritoneal fluid shows a 2.38 fold $(\mathrm{p}<0.05)$ increase after $24 \mathrm{~h}$, a 2.59 fold increase after $48 \mathrm{~h}$, a 4.47 fold $(\mathrm{p}<0.05)$ increase after $72 \mathrm{~h}$ and a 4.89 fold $(\mathrm{p}<0.05)$ increase after 96 $\mathrm{h}$, with TG, as compared to control. Administration of fisetin alone shows a 1.29 fold decrease after $24 \mathrm{~h}$, a 1.26 fold decrease after $48 \mathrm{~h}$, a 1.16 fold decrease after $72 \mathrm{~h}$, and a 1.88 fold decrease after $96 \mathrm{~h}$. With $\mathrm{MCN}+$ fisetin, the NO concentration decreased 1.10 fold after $24 \mathrm{~h}, 1.50$ fold after $48 \mathrm{~h}, 1.13$ fold after $72 \mathrm{~h}$, and 1.49 fold after $96 \mathrm{~h}$. Compared to fisetin, MCN has reduced the NO concentration 1.19 fold only after $48 \mathrm{~h}$ (Table 6 and Figure 6).

\section{NO estimation of BM}

The concentration of NO in the bone marrow shows a 1.55 fold increase after $24 \mathrm{~h}$, a 1.75 fold increase after $48 \mathrm{~h}$, a 1.95 fold $(\mathrm{p}<0.05)$ increase after $72 \mathrm{~h}$ and a 2.12 fold $(\mathrm{p}<0.05)$ increase after $96 \mathrm{~h}$, with TG, as compared to control. Administration of fisetin alone shows a 1.22 fold increase after $24 \mathrm{~h}$, but there is a 2.16 fold $(\mathrm{p}<0.05)$ decrease after 48 $\mathrm{h}$, a 1.36 fold decrease after $72 \mathrm{~h}$, and a 2.29 fold $(\mathrm{p}<0.05)$ decrease after $96 \mathrm{~h}$, compared to only TG. With MCN+fisetin, the NO concentration decreased 1.26 fold after $24 \mathrm{~h}, 2.36$ fold after $48 \mathrm{~h}, 1.23$ fold after $72 \mathrm{~h}$ and 2.57 fold $(\mathrm{p}<0.05)$ after $96 \mathrm{~h}$, compared to only TG. Compared to fisetin, MCN has reduced the NO concentration after $24 \mathrm{~h}$ ( 1.54 fold), $48 \mathrm{~h}$ (1.09 fold) and after $96 \mathrm{~h}$ (1.12 fold) (Table 7 and Figure 7 ).

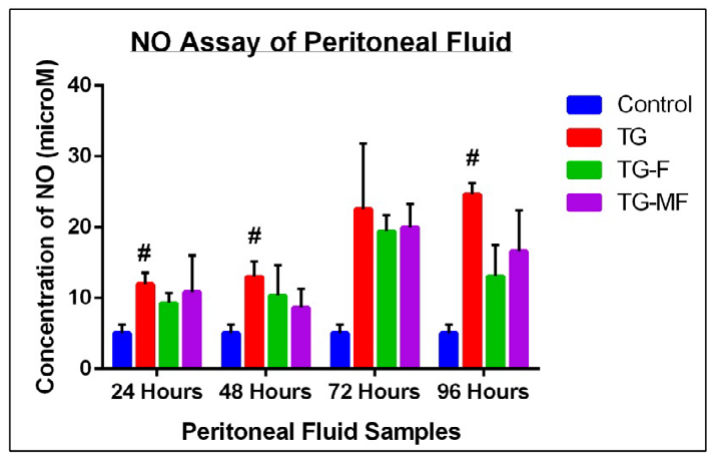

Figure 6: Effect of fisetin and $\mathrm{MCN}+$ fisetin on the production of nitric oxide in the peritoneal fluid (*: $p<0.05$ versus Control; * $p<0.05$ versus TG; *: $p<0.05$ versus TG-F).

\begin{tabular}{|c|c|c|c|c|}
\hline BM & Concentration of NO $(\boldsymbol{\mu M}) \pm$ SEM & \multicolumn{3}{|l|}{ Fold change, with respect to } \\
\hline Control & & Control & TG & TG-F \\
\hline TG24 & $9.46 \pm 1.79$ & & & \\
\hline TG24F & $14.67 \pm 3.84$ & $(+) 1.55$ & & \\
\hline TG24MF & $17.96 \pm 1.56$ & & $(+) 1.22$ & \\
\hline TG48 & $11.65 \pm 3.16$ & & $(-) 1.26$ & $(-) 1.54$ \\
\hline TG48F & $16.57 \pm 2.51$ & $(+) 1.75$ & & \\
\hline TG48MF & $7.66 \pm 1.55$ & & $(-) 2.16^{*}$ & \\
\hline TG72 & $7.03 \pm 1.88$ & & $(-) 2.36$ & $(-) 1.09$ \\
\hline TG72F & $18.49 \pm 0.63$ & $(+) 1.95^{\#}$ & & \\
\hline TG72MF & $13.58 \pm 2.01$ & & $(-) 1.36$ & \\
\hline TG96 & $15.01 \pm 3.96$ & & $(-) 1.23$ & $(+) 1.11$ \\
\hline TG96F & $20.05 \pm 1.32$ & $(+) 2.12^{\#}$ & & \\
\hline TG96MF & $8.74 \pm 1.84$ & & $(-) 2.29^{*}$ & \\
\hline
\end{tabular}

(\#: $p<0.05$ versus Control; *: $p<0.05$ versus TG; * $p<0.05$ versus TG-F)

Table 7: Concentration and fold changes in nitric oxide produced in bone marrow, assayed by Griess Reagent, at $540 \mathrm{~nm}$. With fisetin, there is a 2.16 fold $(p<0.05)$ decrease after $48 \mathrm{~h}$, a 1.36 fold decrease after $72 \mathrm{~h}$ and a 2.29 fold $(p<0.05)$ decrease after $96 \mathrm{~h}$. With $\mathrm{MCN}+$ fisetin, there is a 1.26 fold decrease after $24 \mathrm{~h}$, a 2.36 fold decrease after $48 \mathrm{~h}$, a 1.23 fold decrease after $72 \mathrm{~h}$ and a 2.57 fold $(p<0.05)$ decrease after $96 \mathrm{~h}$.

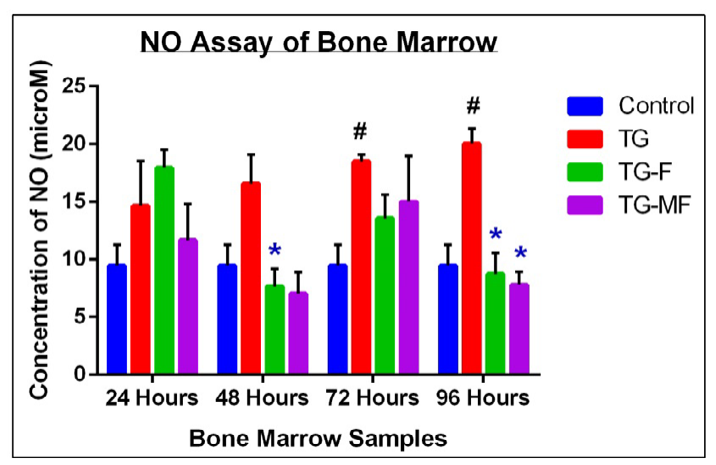

Figure 7: Effect of fisetin and $\mathrm{MCN}+$ fisetin on the production of nitric oxide in the bone marrow (\#: $p<0.05$ versus Control; *: $p<0.05$ versus TG; *: $p<0.05$ versus TG-F). 


\section{Cell proliferation (MTS) assay of PB}

The MTS assay gives an idea about the proliferative potential of the cells. The cell viabilities decreased with TG treatment, as compared to untreated control. There is a 1.23 fold decrease in viability after $24 \mathrm{~h}$, a 1.35 fold decrease after $48 \mathrm{~h}$, a 1.96 fold $(\mathrm{p}<0.05)$ decrease after $72 \mathrm{~h}$ and a 2.33 fold $(\mathrm{p}<0.05)$ decrease after $96 \mathrm{~h}$ of infection. Cell viability increased 1.15 fold after $24 \mathrm{~h}, 1.22$ fold after $48 \mathrm{~h}, 1.26$ fold after $72 \mathrm{~h}$ and 1.43 fold after $96 \mathrm{~h}$, with fisetin, compared to TG. With MCN+ fisetin, viability increased 1.16 fold after $24 \mathrm{~h}, 1.34$ fold after $48 \mathrm{~h}, 1.24$ fold after $72 \mathrm{~h}$ and 1.22 fold $(\mathrm{p}<0.05)$ after $96 \mathrm{~h}$. Compared to only fisetin, MCN increased the viability of the cells by 1.01 fold after $24 \mathrm{~h}$ and by 1.10 fold after $48 \mathrm{~h}$ (Table 8 and Figure 8 ).

\section{Cell proliferation (MTS) assay of PF}

The viability of cells in the PF decreased 1.23 fold after $24 \mathrm{~h}, 1.31$ fold after $48 \mathrm{~h}, 1.64$ fold after $72 \mathrm{~h}$ and 1.70 fold after $96 \mathrm{~h}$. With fisetin, compared to only TG, cell viability increased 1.15 fold after $24 \mathrm{~h}, 1.23$ fold after $48 \mathrm{~h}, 1.39$ fold after $72 \mathrm{~h}$ and 1.42 fold after $96 \mathrm{~h}$. Viability increased 1.16 fold after $24 \mathrm{~h}, 1.10$ fold after $48 \mathrm{~h}, 1.60$ fold after 72 $\mathrm{h}$ and 1.35 fold after $96 \mathrm{~h}$, with $\mathrm{MCN}+$ fisetin treatment, compared to only TG. MCN increased viability, compared to only fisetin, by 1.01

\begin{tabular}{|c|c|c|c|c|c|}
\hline PB & $\begin{array}{c}\text { Absorbance } \\
\mathbf{n m} \mathbf{4} \pm \mathbf{S E M}\end{array}$ & \% viability & \multicolumn{3}{|c|}{ Fold change, with respect to } \\
\cline { 6 - 7 } & & Control & TG & TG-F \\
\hline Control & $2.321 \pm 0.25$ & 100.00 & & & \\
\hline TG24 & $1.887 \pm 0.45$ & 81.30 & $(-) 1.23$ & & \\
\hline TG24F & $2.164 \pm 0.37$ & 93.23 & & $(+) 1.15$ & \\
\hline TG24MF & $2.193 \pm 0.07$ & 94.48 & & $(+) 1.16$ & $(+) 1.01$ \\
\hline TG48 & $1.725 \pm 0.29$ & 74.33 & $(-) 1.35$ & & \\
\hline TG48F & $2.102 \pm 0.11$ & 90.58 & & $(+) 1.22$ & \\
\hline TG48MF & $2.317 \pm 0.06$ & 99.82 & & $(+) 1.34$ & $(+) 1.10$ \\
\hline TG72 & $1.186 \pm 0.32$ & 51.11 & $(-) 1.96^{\#}$ & & \\
\hline TG72F & $1.499 \pm 0.33$ & 64.61 & & $(+) 1.26$ & \\
\hline TG72MF & $1.466 \pm 0.12$ & 63.19 & & $(+) 1.24$ & $(-) 1.02$ \\
\hline TG96 & $0.995 \pm 0.21$ & 42.89 & $(-) 2.33^{\#}$ & & \\
\hline TG96F & $1.419 \pm 0.20$ & 61.13 & & $(+) 1.43$ & \\
\hline TG96MF & $1.215 \pm 0.11$ & 52.34 & & $(+) 1.22$ & $(-) 1.17$ \\
\hline
\end{tabular}

(\#: $p<0.05$ versus Control; *: $p<0.05$ versus TG; *: $p<0.05$ versus TG-F)

Table 8: Fold changes in viability of cells in peripheral blood, assayed by MTS reagent, at $492 \mathrm{~nm}$. With fisetin, there is a 1.15 fold increase after $24 \mathrm{~h}$, a 1.22 fold increase after $48 \mathrm{~h}$, a 1.26 fold increase after $72 \mathrm{~h}$ and a 1.43 fold increase after $96 \mathrm{~h}$. With $\mathrm{MCN}+$ fisetin, there is a 1.16 fold increase after $24 \mathrm{~h}$, a 1.34 fold increase after $48 \mathrm{~h}$, a 1.24 fold increase after $72 \mathrm{~h}$ and a 1.22 fold $(p<0.05)$ increase after $96 \mathrm{~h}$.

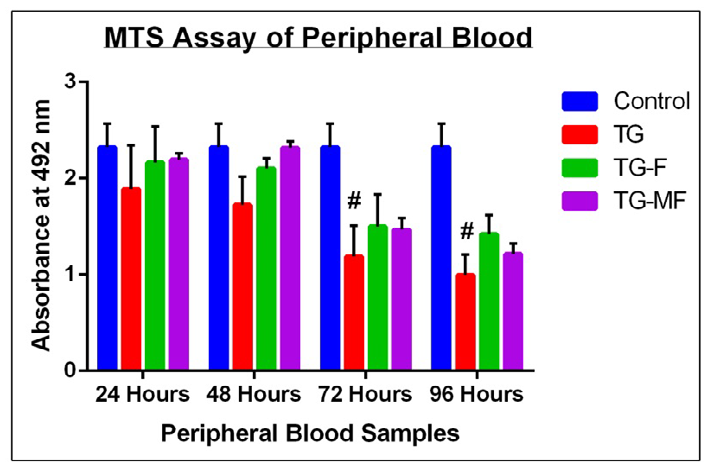

Figure 8: Effect of fisetin and $\mathrm{MCN}+$ fisetin on viability of cells in the peripheral blood (": $p<0.05$ versus Control; *: $p<0.05$ versus TG; *: $p<0.05$ versus TG-F).

\begin{tabular}{|c|c|c|c|c|c|}
\hline PF & $\begin{array}{c}\text { Absorbance } \\
\mathbf{n m} \mathbf{4} \mathbf{S E M}\end{array}$ & \% viability & \multicolumn{3}{|c|}{ Fold change, with respect to } \\
\cline { 5 - 6 } & & & Control & TG & TG-F \\
\hline Control & $0.945 \pm 0.11$ & 100.00 & & & \\
\hline TG24 & $0.769 \pm 0.08$ & 81.33 & $(-) 1.23$ & & \\
\hline TG24F & $0.882 \pm 0.27$ & 93.29 & & $(+) 1.15$ & \\
\hline TG24MF & $0.891 \pm 0.20$ & 94.31 & & $(+) 1.16$ & $(+) 1.01$ \\
\hline TG48 & $0.722 \pm 0.18$ & 76.42 & $(-) 1.31$ & & \\
\hline TG48F & $0.892 \pm 0.05$ & 94.36 & & $(+) 1.23$ & \\
\hline TG48MF & $0.793 \pm 0.21$ & 83.85 & & $(+) 1.10$ & $(-) 1.13$ \\
\hline TG72 & $0.577 \pm 0.09$ & 61.06 & $(-) 1.64$ & & \\
\hline TG72F & $0.804 \pm 0.02$ & 85.08 & & $(+) 1.39$ & \\
\hline TG72MF & $0.921 \pm 0.24$ & 97.50 & & $(+) 1.60$ & $(+) 1.15$ \\
\hline TG96 & $0.554 \pm 0.17$ & 58.66 & $(-) 1.70$ & & \\
\hline TG96F & $0.785 \pm 0.17$ & 83.11 & & $(+) 1.42$ & \\
\hline TG96MF & $0.750 \pm 0.24$ & 79.33 & & $(+) 1.35$ & $(-) 1.05$ \\
\hline
\end{tabular}

(\#: $p<0.05$ versus Control; *: $p<0.05$ versus TG; *: $p<0.05$ versus TG-F)

Table 9: Fold changes in viability of cells in peritoneal fluid, assayed by MTS reagent, at $492 \mathrm{~nm}$. With fisetin, there is a 1.15 fold increase after $24 \mathrm{~h}$, a 1.23 fold increase after $48 \mathrm{~h}$, a 1.39 fold increase after $72 \mathrm{~h}$ and a 1.42 fold increase after 96 $\mathrm{h}$, in the cell viability. With $\mathrm{MCN}+$ fisetin, cell viability increased 1.16 fold after $24 \mathrm{~h}$, 1.10 fold after $48 \mathrm{~h}, 1.60$ fold after $72 \mathrm{~h}$ and 1.35 fold after $96 \mathrm{~h}$.

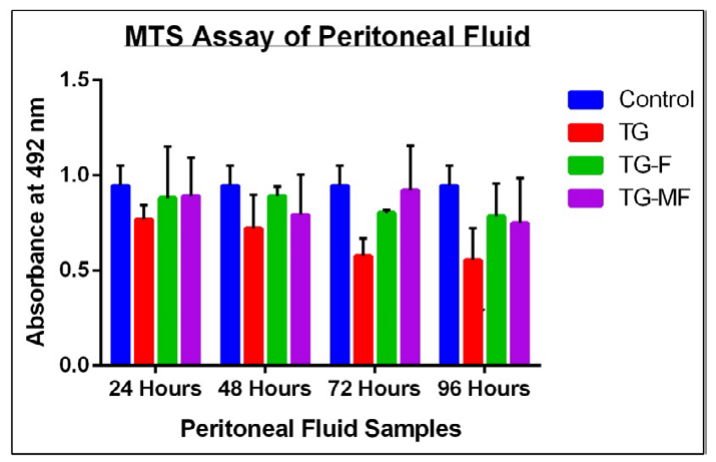

Figure 9: Effect of fisetin and $\mathrm{MCN}+$ fisetin on viability of cells in the peritoneal fluid (*: $p<0.05$ versus Control; *: $p<0.05$ versus TG; *: $p<0.05$ versus TG-F).

fold after $24 \mathrm{~h}$ and by 1.15 fold after $72 \mathrm{~h}$ (Table 9 and Figure 9).

\section{Cell proliferation (MTS) assay of BM}

The viability of cells in the BM decreased 1.15 fold after $24 \mathrm{~h}, 1.24$ fold after $48 \mathrm{~h}, 1.37$ fold after $72 \mathrm{~h}$ and 1.49 fold after $96 \mathrm{~h}$ of treatment with TG, compared to control. Viability increased 1.06 fold after $24 \mathrm{~h}$, 1.18 fold after $48 \mathrm{~h}, 1.10$ fold after $72 \mathrm{~h}$ and 1.31 fold $(\mathrm{p}<0.05)$ after 96 $\mathrm{h}$, with fisetin, compared to only TG. With $\mathrm{MCN}+$ fisetin, compared to TG, viability increased 1.08 fold after $24 \mathrm{~h}, 1.09$ fold after $48 \mathrm{~h}, 1.29$ fold after $72 \mathrm{~h}$ and 1.22 fold after $96 \mathrm{~h}$. Addition of MCN to fisetin improved viability by 1.02 fold after $24 \mathrm{~h}$, and by 1.17 fold after $72 \mathrm{~h}$ (Table 10 and Figure 10).

\section{CFU-c assay of PB}

CFU-c assay gives the clonogenic potential of cells, which is the ability of cells to form colonies on a semi- solid matrix. The clonogenic potential of cells in the peripheral blood decreased with TG treatment, as compared to control. There is a 1.63 fold $(\mathrm{p}<0.05)$ decrease after 24 h, a 2.82 fold $(\mathrm{p}<0.05)$ decrease after $48 \mathrm{~h}$, a 3.65 fold $(\mathrm{p}<0.05)$ decrease after $72 \mathrm{~h}$ and a 5.17 fold $(\mathrm{p}<0.05)$ decrease after $96 \mathrm{~h}$, with TG. It increased 1.26 fold after $24 \mathrm{~h}, 1.05$ fold after $48 \mathrm{~h}$ and 1.75 fold after $96 \mathrm{~h}$, with fisetin treatment, but decreased 1.06 fold after $72 \mathrm{~h}$. With 
Citation: Mitra S, Biswas S, Sinha A, Jana NR, Banerjee ER (2015) Therapeutic use of Fisetin and Fisetin Loaded on Mesoporous Carbon Nanoparticle (MCN) in Thioglycollate-induced Peritonitis. J Nanomed Nanotechnol 6: 332. doi:10.4172/2157-7439.1000332

Page 8 of 12

\begin{tabular}{|c|c|c|c|c|c|}
\hline BM & $\begin{array}{c}\text { Absorbance } \\
\mathbf{n m} \mathbf{4} \pm \mathbf{S E M}\end{array}$ & $\%$ viability & \multicolumn{3}{|c|}{ Fold change, with respect to } \\
\cline { 5 - 6 } & & Control & TG & TG-F \\
\hline Control & $1.44 \pm 0.51$ & 100.00 & & & \\
\hline TG24 & $1.25 \pm 0.16$ & 81.33 & $(-) 1.15$ & & \\
\hline TG24F & $1.33 \pm 0.49$ & 93.29 & & $(+) 1.06$ & \\
\hline TG24MF & $1.35 \pm 0.05$ & 94.31 & & $(+) 1.08$ & $(+) 1.02$ \\
\hline TG48 & $1.16 \pm 0.22$ & 76.42 & $(-) 1.24$ & & \\
\hline TG48F & $1.37 \pm 0.23$ & 94.36 & & $(+) 1.18$ & \\
\hline TG48MF & $1.27 \pm 0.32$ & 83.85 & & $(+) 1.09$ & $(-) 1.08$ \\
\hline TG72 & $1.05 \pm 0.24$ & 61.06 & $(-) 1.37$ & & \\
\hline TG72F & $1.16 \pm 0.23$ & 85.08 & & $(+) 1.10$ & \\
\hline TG72MF & $1.36 \pm 0.07$ & 87.31 & & $(+) 1.29$ & $(+) 1.17$ \\
\hline TG96 & $0.97 \pm 0.07$ & 58.66 & $(-) 1.49$ & & \\
\hline TG96F & $1.27 \pm 0.06$ & 83.11 & & $(+) 1.31^{*}$ & \\
\hline TG96MF & $1.19 \pm 0.10$ & 79.33 & & $(+) 1.22$ & $(-) 1.07$ \\
\hline
\end{tabular}

(": $p<0.05$ versus Control; *: $p<0.05$ versus TG; *: $p<0.05$ versus TG-F)

Table 10: Fold changes in viability of cells in bone marrow, assayed by MTS reagent, at $492 \mathrm{~nm}$. With fisetin, there is a 1.06 fold increase in cell viability after $24 \mathrm{~h}$, a 1.18 fold increase after $48 \mathrm{~h}$, a 1.10 fold increase after $72 \mathrm{~h}$, and a 1.31 fold $(p<0.05)$ increase after $96 \mathrm{~h}$. With $\mathrm{MCN}+$ fisetin, there is a 1.08 fold after 24 h, a 1.09 fold increase after 48 h, a 1.29 fold increase after $72 \mathrm{~h}$ and a 1.22 fold increase after $96 \mathrm{~h}$.

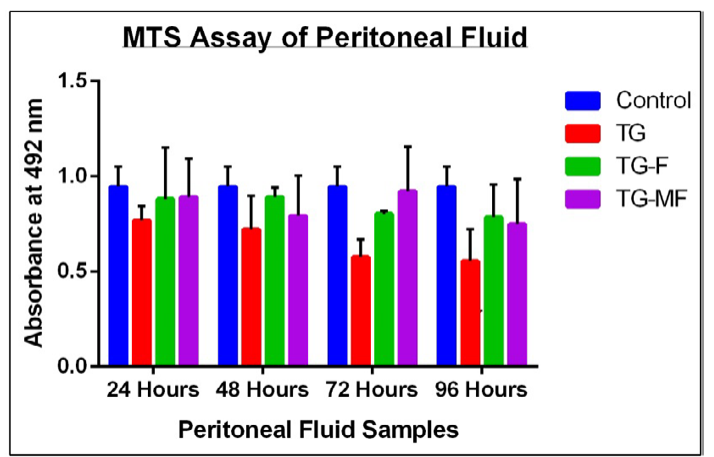

Figure 10: Effect of fisetin and MCN+fisetin on viability of cells in the bone marrow (": $p<0.05$ versus Control; *: $p<0.05$ versus TG; *: $p<0.05$ versus TG-F).

$\mathrm{MCN}+$ fisetin, the clonogenic potential increased 1.45 fold after $24 \mathrm{~h}$ and 1.65 fold after $72 \mathrm{~h}$. MCN has enhanced the clonogenic potential by 1.15 fold after $24 \mathrm{~h}$ and by 1.75 fold after $72 \mathrm{~h}$ (Table 11 and Figure 11 ).

\section{CFU-c assay of PF}

The clonogenic potential of cells in PF decreased 1.33 fold after 24 h, 2.00 fold after 48 h, 2.29 fold after $72 \mathrm{~h}$ and 3.20 fold after $96 \mathrm{~h}$, with TG treatment. Compared to TG, with fisetin treatment, it increased 1.42 fold after $24 \mathrm{~h}, 1.75$ fold after $48 \mathrm{~h}, 1.71$ fold after $72 \mathrm{~h}$ and 3.20 fold after $96 \mathrm{~h}$. With MCN+fisetin, the clonogenic potential increased 1.33 fold after $24 \mathrm{~h}, 1.38$ fold after $48 \mathrm{~h}, 2.14$ fold after $72 \mathrm{~h}$ and 6.80 fold after $96 \mathrm{~h}$. Compared to fisetin, MCN has improved the clonogenic potential by 1.25 fold after $72 \mathrm{~h}$ and by 2.13 fold after $96 \mathrm{~h}$ (Table 12 and Figures 12-14).

\section{CFU-c assay of BM}

The clonogenic potential of cells in the bone marrow decreases with TG treatment, as compared to control. There is a 1.73 fold decrease $(\mathrm{p}<0.05)$ after $24 \mathrm{~h}$, a 2.52 fold decrease $(\mathrm{p}<0.05)$ after $48 \mathrm{~h}$, a 3.39 fold decrease $(\mathrm{p}<0.05)$ after $72 \mathrm{~h}$ and a 4.59 fold $(\mathrm{p}<0.05)$ decrease after 96 $\mathrm{h}$, with TG. It increases 1.20 fold after $24 \mathrm{~h}, 1.03$ fold after $48 \mathrm{~h}$ and 1.53 fold after $96 \mathrm{~h}$, with fisetin, compared to TG. With MCN+fisetin,

\begin{tabular}{|c|c|c|c|c|}
\hline PB & Clonogenic Potential $\left(\mathbf{x} \mathbf{1 0}^{-5}\right) \pm$ SEM & \multicolumn{3}{|l|}{ Fold change, with respect to } \\
\hline & & Control & TG & TG-F \\
\hline Control & $3.10 \pm 0.10$ & & & \\
\hline TG24 & $1.90 \pm 0.10$ & $(-) 1.63^{\#}$ & & \\
\hline TG24F & $2.40 \pm 0.20$ & & $(+) 1.26$ & \\
\hline TG24MF & $2.75 \pm 0.25$ & & $(+) 1.45$ & $(+) 1.15$ \\
\hline TG48 & $1.10 \pm 0.20$ & $(-) 2.82^{\#}$ & & \\
\hline TG48F & $1.15 \pm 0.25$ & & $(+) 1.05$ & \\
\hline TG48MF & $0.85 \pm 0.05$ & & $(-) 1.29$ & $(-) 1.35$ \\
\hline TG72 & $0.85 \pm 0.25$ & $(-) 3.65^{\#}$ & & \\
\hline TG72F & $0.80 \pm 0.10$ & & $(-) 1.06$ & \\
\hline TG72MF & $1.40 \pm 0.10$ & $(-) 5.17^{\#}$ & & \\
\hline TG96 & $0.60 \pm 0.10$ & & $(+) 1.65$ & $(+) 1.75$ \\
\hline TG96F & $1.05 \pm 0.55$ & & $(-) 1.50$ & $(-) 2.63^{*}$ \\
\hline TG96MF & $0.40 \pm 0.10$ & & & \\
\hline & & & & \\
\hline
\end{tabular}

(\#: $p<0.05$ versus Control; *: $p<0.05$ versus TG; * $p<0.05$ versus TG-F)

Table 11: The change in clonogenic potential of cells in the peripheral blood, assessed by CFU-c assay using methyl cellulose. There is an increase in clonogenic potential after $24 \mathrm{~h}$ ( 1.26 fold), after $48 \mathrm{~h}$ ( 1.05 fold $)$ and after $96 \mathrm{~h}$ ( 1.75 fold), with fisetin treatment. With $\mathrm{MCN}+$ fisetin, there is an increase in clonogenic potential after $24 \mathrm{~h}$ ( 1.45 fold) and after $72 \mathrm{~h}$ ( 1.65 fold).

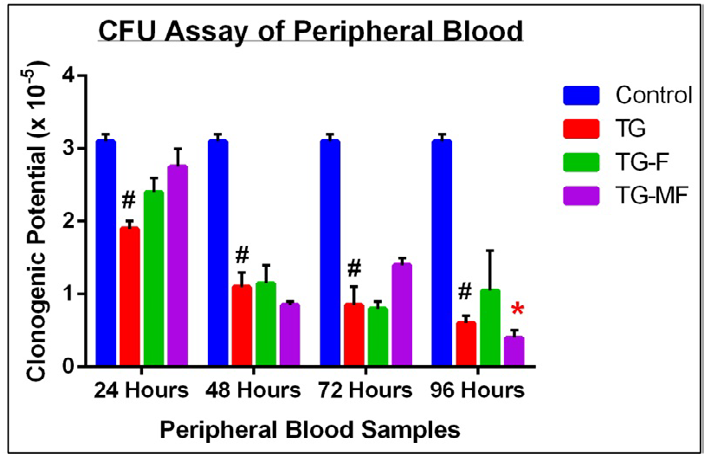

Figure 11: Effect of fisetin and MCN+fisetin on the clonogenic potential of cells in the peripheral blood (\#: $p<0.05$ versus Control; *: $p<0.05$ versus TG; *: $p<0.05$ versus TG-F).

\begin{tabular}{|c|c|c|c|c|}
\hline PF & Clonogenic Potential $\left(\mathbf{x} 10^{-4}\right) \pm$ SEM & \multicolumn{3}{|l|}{ Fold change, with respect to } \\
\hline & & Control & TG & TG-F \\
\hline Control & $0.80 \pm 0.20$ & & & \\
\hline TG24 & $0.60 \pm 0.10$ & $(-) 1.33$ & & \\
\hline TG24F & $0.85 \pm 0.05$ & & $(+) 1.42$ & \\
\hline TG24MF & $0.80 \pm 0.40$ & & $(+) 1.33$ & $(-) 1.06$ \\
\hline TG48 & $0.40 \pm 0.10$ & $(-) 2.00$ & & \\
\hline TG48F & $0.70 \pm 0.10$ & & $(+) 1.75$ & \\
\hline TG48MF & $0.55 \pm 0.15$ & & $(+) 1.38$ & $(-) 1.27$ \\
\hline TG72 & $0.35 \pm 0.05$ & $(-) 2.29$ & & \\
\hline TG72F & $0.60 \pm 0.10$ & & $(+) 1.71$ & \\
\hline TG72MF & $0.75 \pm 0.15$ & $(-) 3.20$ & & \\
\hline TG96 & $0.25 \pm 0.05$ & & $(+) 2.14$ & $(+) 1.25$ \\
\hline TG96F & $0.80 \pm 0.40$ & & $(+) 6.80$ & $(+) 2.13$ \\
\hline TG96MF & $1.70 \pm 0.60$ & & & \\
\hline
\end{tabular}

(*: $p<0.05$ versus Control; *: $p<0.05$ versus TG; *: $p<0.05$ versus TG-F)

Table 12: The change in clonogenic potential of cells in the peritoneal fluid, assessed by CFU-c assay using methyl cellulose. There is an increase in clonogenic potential after $24 \mathrm{~h}$ (1.42 fold), $48 \mathrm{~h}$ (1.75 fold), $72 \mathrm{~h}$ (1.71 fold) and $96 \mathrm{~h}$ ( 3.20 fold), with fisetin treatment. With MCN+fisetin, the clonogenic potential increased by 1.33 fold after $24 \mathrm{~h}, 1.38$ fold after $48 \mathrm{~h}, 2.14$ fold after $72 \mathrm{~h}$ and 6.80 fold after $96 \mathrm{~h}$. 
Citation: Mitra S, Biswas S, Sinha A, Jana NR, Banerjee ER (2015) Therapeutic use of Fisetin and Fisetin Loaded on Mesoporous Carbon Nanoparticle (MCN) in Thioglycollate-induced Peritonitis. J Nanomed Nanotechnol 6: 332. doi:10.4172/2157-7439.1000332

Page 9 of 12
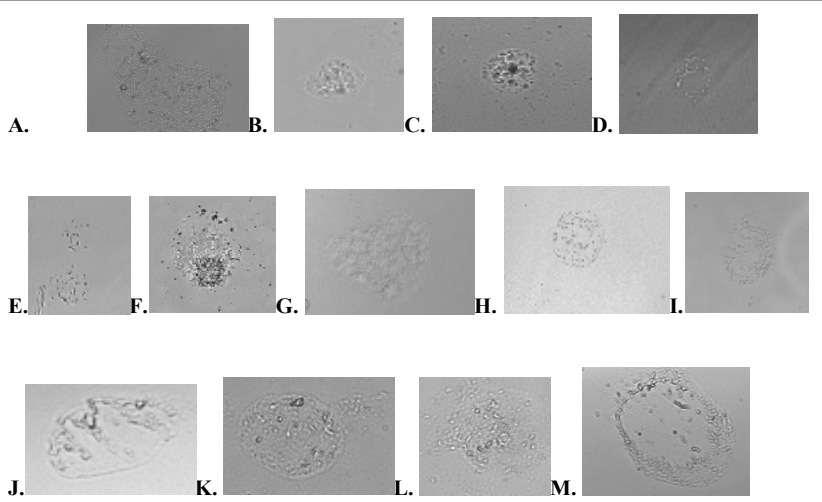

A.Control; B. TG24; C. TG24F; D. TG24MF; E. TG48; F. TG48F; G. TG48MF; H. TG72; I. TG72F; J. TG72MF; K. TG96; L. TG96F; M. TG96MF.

Figure 12: Effect of fisetin and $\mathrm{MCN}+$ fisetin on the clonogenic potential of cells in the peripheral blood, as seen under Floid Cell Imaging Station.

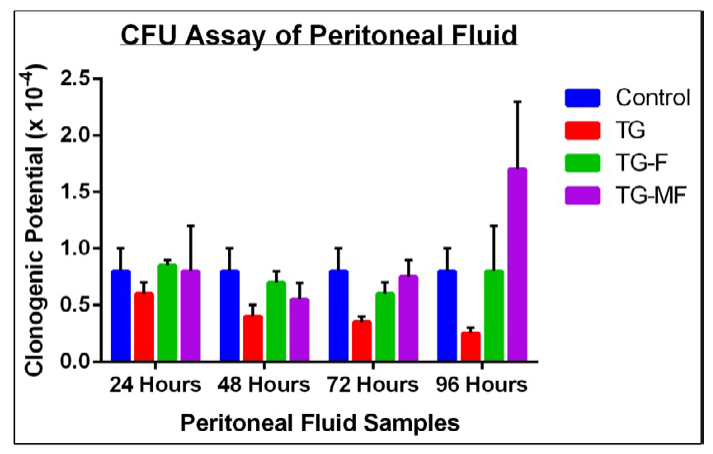

Figure 13: Effect of fisetin and $\mathrm{MCN}+$ fisetin on the clonogenic potential of cells in the peritoneal fluid (\#: $p<0.05$ versus Control; *: $p<0.05$ versus TG; *: $p<0.05$ versus TG-F).
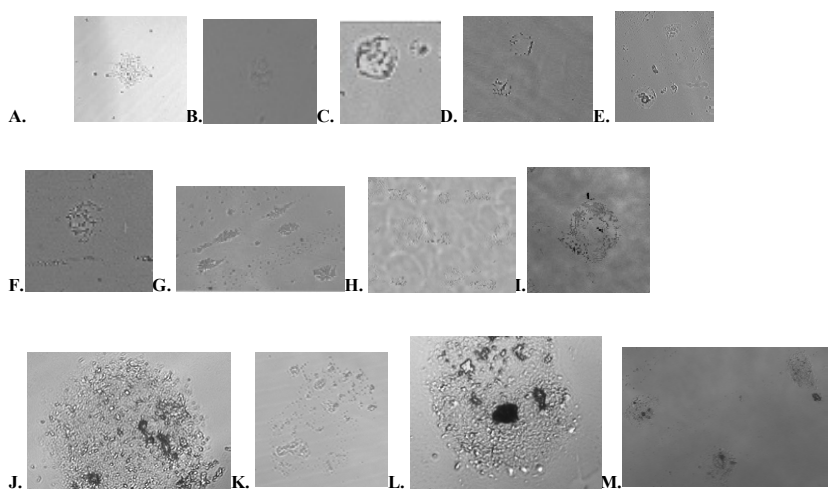

A. Control; B. TG24; C. TG24F; D. TG24MF; E. TG48; F. TG48F; G. TG48MF; H. TG72; I. TG72F; J. TG72MF; K. TG96; L. TG96F; M. TG96MF.

Figure 14: Effect of fisetin and $\mathrm{MCN}+$ fisetin on the clonogenic potential of cells in the peritoneal fluid, as seen under Floid Cell Imaging Station.

the clonogenic potential increased 1.33 fold after $24 \mathrm{~h}, 1.61$ fold after $72 \mathrm{~h}$ and 1.88 fold after $96 \mathrm{~h}$, but has decreased 1.24 fold after $48 \mathrm{~h}$, compared to fisetin, $\mathrm{MCN}$ has increased the clonogenic potential by 1.11 fold after $24 \mathrm{~h}, 1.68$ fold after $72 \mathrm{~h}$ and 1.23 fold after $96 \mathrm{~h}$ (Table 13, Figures 15 and 16).

\begin{tabular}{|c|c|c|c|c|}
\hline \multirow[t]{2}{*}{ BM } & \multirow[t]{2}{*}{ Clonogenic Potential $\left(\times 10^{-5}\right) \pm$ SEM } & \multicolumn{3}{|c|}{ Fold change, with respect to } \\
\hline & & Control & TG & TG-F \\
\hline Control & $0.80 \pm 0.20$ & & & \\
\hline TG24 & $0.60 \pm 0.10$ & $(-) 1.33$ & & \\
\hline TG24F & $0.85 \pm 0.05$ & & $(+) 1.42$ & \\
\hline TG24MF & $0.80 \pm 0.40$ & & $(+) 1.33$ & $(-) 1.06$ \\
\hline TG48 & $0.40 \pm 0.10$ & $(-) 2.00$ & & \\
\hline TG48F & $0.70 \pm 0.10$ & & $(+) 1.75$ & \\
\hline TG48MF & $0.55 \pm 0.15$ & & $(+) 1.38$ & $(-) 1.27$ \\
\hline TG72 & $0.35 \pm 0.05$ & $(-) 2.29$ & & \\
\hline TG72F & $0.60 \pm 0.10$ & & $(+) 1.71$ & \\
\hline TG72MF & $0.75 \pm 0.15$ & & $(+) 2.14$ & $(+) 1.25$ \\
\hline TG96 & $0.25 \pm 0.05$ & $(-) 3.20$ & & \\
\hline TG96F & $0.80 \pm 0.40$ & & $(+) 3.20$ & \\
\hline TG96MF & $1.70 \pm 0.60$ & & $(+) 6.80$ & $(+) 2.13$ \\
\hline
\end{tabular}

(\#: $p<0.05$ versus Control; * $: p<0.05$ versus TG; *: $p<0.05$ versus TG-F)

Table 13: The change in clonogenic potential of cells in the bone marrow, assessed by CFU-c assay using methyl cellulose. There is an increase in clonogenic potential after $24 \mathrm{~h}$ ( 1.20 fold $), 48 \mathrm{~h}$ ( 1.03 fold $)$, and $96 \mathrm{~h}$ ( $1.53 \mathrm{fold})$, with fisetin treatment With $\mathrm{MCN}+$ fisetin, the clonogenic potential increased by 1.33 fold after $24 \mathrm{~h}, 1.61$ fold after $72 \mathrm{~h}$ and 1.88 fold after $96 \mathrm{~h}$.

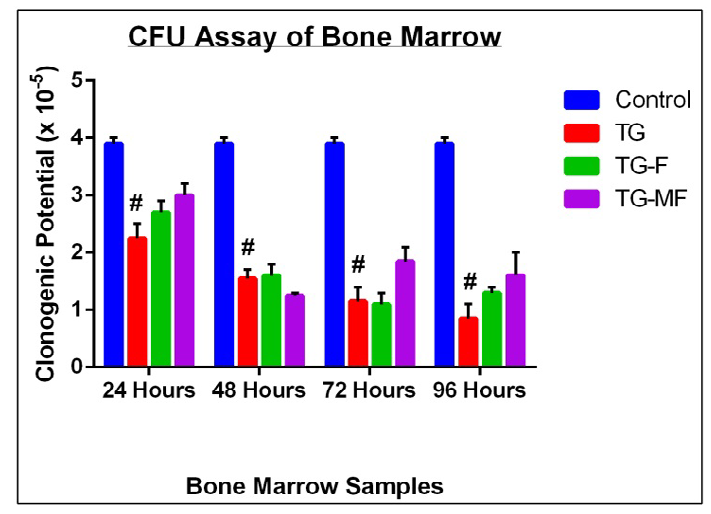

Figure 15: Effect of fisetin and $\mathrm{MCN}+$ fisetin on the clonogenic potential of cells in the bone marrow (\#: $p<0.05$ versus Control; *: $p<0.05$ versus TG; *: $p<0.05$ versus TG-F).
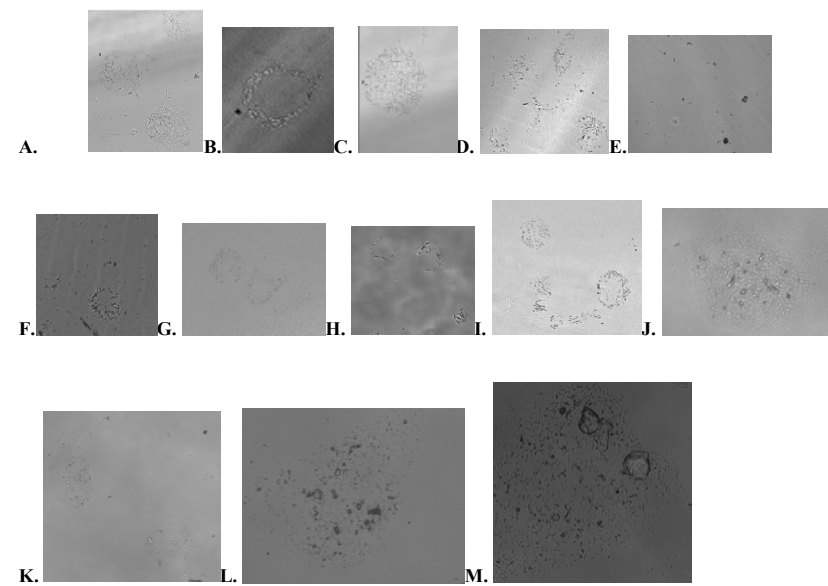

A.Control; B. TG24; C. TG24F; D. TG24MF; E. TG48; F. TG48F; G. TG48MF; H. TG72; I. TG72F; J. TG72MF; K. TG96; L. TG96F; M. TG96MF.

Figure 16: Effect of fisetin and $\mathrm{MCN}+$ fisetin on the clonogenic potential of cells in the peritoneal fluid, as seen under Floid Cell Imaging Station. 


\section{Cytokine levels in peripheral blood after $48 \mathrm{~h}$ of treatment}

$48 \mathrm{~h}$ after challenge with TG, there is an increase in the levels of, IL-4 (1.03 fold), and IFN- $\gamma$ (1.13 fold), and a decrease in the levels of IL-2 (1.06 fold, $\mathrm{p}<0.05)$, IL-5 (1.05 fold) and TNF- $\alpha$ (1.05 fold) compared to control. Compared to TG treated groups, there is an increase in the levels of the cytokines with fisetin treatment $\{1.13$ fold for IL-2, 1.12 fold $(\mathrm{p}<0.05)$ for IL-4, 1.10 fold for IL-5, 1.03 fold for IFN- $\gamma, 1.02$ fold for TNF- $\alpha$, and with MCN+F treatment $\{1.12$ fold for IL-2, 1.27 fold $(\mathrm{p}<0.05)$ for IL-4, 1.14 fold for IL-5, 1.07 fold for IFN- $\gamma, 1.03$ fold for TNF-a (Table 14 and Figure 17).

\section{Discussion}

The pathophysiology of peritonitis is complicated and is involved in various processes, of which, the most important one is the inflammatory

\begin{tabular}{|c|c|c|c|c|c|}
\hline \multirow[t]{2}{*}{ Cytokine } & \multirow[t]{2}{*}{ Treatment } & \multirow{2}{*}{$\begin{array}{c}\text { Concentration of } \\
\text { cytokine }(\mathrm{pg} / \mathrm{ml}) \pm \text { SEM }\end{array}$} & \multicolumn{3}{|c|}{ Fold change, with respect to } \\
\hline & & & Control & TG & TG-F \\
\hline \multirow[t]{4}{*}{ IL-2 } & Control & $19.05 \pm 0.15$ & & & \\
\hline & TG48 & $18.05 \pm 0.15$ & $(-) 1.06^{\#}$ & & \\
\hline & TG48F & $20.40 \pm 0.70$ & & $(+) 1.13$ & \\
\hline & TG48MF & $20.25 \pm 1.15$ & & $(+) 1.12$ & $(-) 1.01$ \\
\hline \multirow[t]{4}{*}{ IL-4 } & Control & $15.25 \pm 0.05$ & & & \\
\hline & TG48 & $15.65 \pm 0.35$ & $(+) 1.03$ & & \\
\hline & TG48F & $17.50 \pm 0.20$ & & $(+) 1.12^{*}$ & \\
\hline & TG48MF & $19.85 \pm 0.95$ & & $(+) 1.27^{*}$ & $(+) 1.13$ \\
\hline \multirow[t]{4}{*}{ IL-5 } & Control & $14.60 \pm 0.20$ & & & \\
\hline & TG48 & $13.85 \pm 0.55$ & $(-) 1.05$ & & \\
\hline & TG48F & $15.30 \pm 0.30$ & & $(+) 1.10$ & \\
\hline & TG48MF & $15.85 \pm 1.75$ & & $(+) 1.14$ & $(+) 1.04$ \\
\hline \multirow[t]{4}{*}{ IFN-Y } & Control & $10.75 \pm 0.45$ & & & \\
\hline & TG48 & $12.10 \pm 0.30$ & $(+) 1.13$ & & \\
\hline & TG48F & $12.45 \pm 1.65$ & & $(+) 1.03$ & \\
\hline & TG48MF & $12.90 \pm 1.60$ & & $(+) 1.07$ & $(+) 1.04$ \\
\hline \multirow[t]{4}{*}{ TNF- $\alpha$} & Control & $10.80 \pm 1.10$ & & & \\
\hline & TG48 & $10.30 \pm 0.30$ & (-) 1.05 & & \\
\hline & TG48F & $10.55 \pm 1.05$ & & (+) 1.02 & \\
\hline & TG48MF & $10.60 \pm 1.40$ & & (+) 1.03 & (+) 1.01 \\
\hline
\end{tabular}

(": $p<0.05$ versus Control; *: $p<0.05$ versus TG; *: $p<0.05$ versus TG-F)

Table 14: Concentration (in pg/ml) of cytokines IL-2, IL-4, IL-5, IFN- $\gamma$ and TNF- $\alpha$, in peripheral blood, after $48 \mathrm{~h}$ of treatment, assayed using BD CBA Mouse Th1/Th2 Cytokine Kit. Cytokine analysis shows an increase in the levels of the cytokines with both, fisetin and $\mathrm{MCN}+$ fisetin, compared to TG.

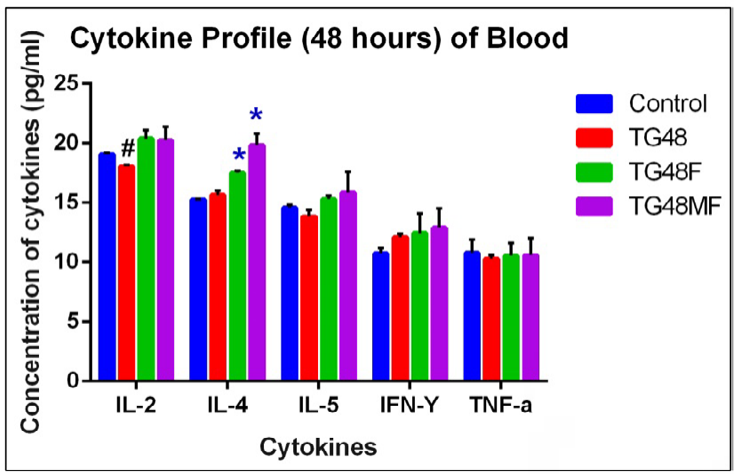

Figure 17: Effect of fisetin and $\mathrm{MCN}+$ fisetin on the cytokine profile of peripheral blood (": $p<0.05$ versus Control; *: $p<0.05$ versus TG; *: $p<0.05$ versus TG-F). reaction [27]. During the pathological process of the peritonitis, NF- $\kappa \mathrm{B}$ plays an activating role in the inflammatory reaction [7].

Our study was designed to investigate the potential therapeutic effects of fisetin and fisetin loaded on mesoporous carbon nanoparticle (MCN) on the thioglycollate-induced peritonitis in rodent models. The thioglycollate-induced peritonitis in mice is used as a model to study the potential anti-inflammatory action of investigated test compounds [28]. In this present study, we have induced peritonitis in 6-8 weeks old $\mathrm{BALB} / \mathrm{c}$ mice using thioglycollate, and then assessed the antiinflammatory effects of plant flavonoid, fisetin, when administered therapeutically. We have also assesses the anti-inflammatory effects of fisetin, when administered with a nanovehicle, mesoporous carbon nanoparticle. We found that fisetin had a positive therapeutic effect on the peritonitis.

Acute peritonitis differs from other infections because of the broad variety of causes, severity of the infection [29]. Acute peritonitis is one of the most headachy postoperative complications, which was an important cause of death in surgical practice and intensive care units [9]. The most serious consequence of acute peritonitis is sepsis, often leading to an unacceptably high morbidity and mortality [30]. So the research of acute peritonitis is always the hotspot of surgery and critical care medicine. The animal model is one of the most important methods in the scientific research. It can not only provide convenience in deriving a better understanding of the pathophysiology of disease, but also provide important and indispensable tools to explore the therapy of disease. It is the bridge between the fundamental research and clinical application.

The process of peritonitis is mediated by the activation of inducible transcription factors, such as NF- $\kappa \mathrm{B}$, which play a pivotal role in the immune and inflammatory responses. Previous investigators have found that acute peritonitis and sepsis were associated with the activation of the transcription factor NF- $\mathrm{BB}$ in various organs and tissues $[10,31,32]$ which can regulate the synthesis of TNF- $\alpha$, IL-6, inducible nitric oxide synthase, cyclooxigenase- 2 and many other molecules involved in the inflammatory reaction $[18,33]$.

In this study, we found that, with administration of TG, cell recruitment in the blood increases progressively with time, with maximum recruitment after $96 \mathrm{~h}$. This shows that it has induced inflammation, and the body is synthesizing more immune cells to counter the infection. Cell recruitment is successfully inhibited by fisetin, and with $\mathrm{MCN}+$ fisetin. In the peritoneal fluid, total cell recruitment was increased, which was successfully inhibited with fisetin and $\mathrm{MCN}+$ fisetin treatments.

Nitric acid is produced by macrophages as a defense against oxidative stress. In case of inflammation, NO content is expected to increase. Our assays have shown that the NO content of the tissues was increased with TG challenge. NO content decreased with fisetin and with MCN+fisetin. However, the addition of MCN to fisetin did not make a significant difference to the $\mathrm{NO}$ content.

We found that, TG treatment significantly reduced cell proliferation in the blood, PF and BM. Interestingly, cell proliferation was increased with fisetin treatment, and with $\mathrm{MCN}+$ fisetin. In another assay, the clonogenic potential of the tissues decreases significantly within $24 \mathrm{~h}$, with administration of TG. Both fisetin treatment and MCN+fisetin treatment have restored the clonogenic potential of the tissues. Our study demonstrated that, there was a decrease in Th2 cytokines (IL-2, IL-5 and TNF- $\alpha$ ) with TG treatment, in blood after $48 \mathrm{~h}$ and fisetin and $\mathrm{MCN}+$ fisetin was increased the cytokine content. However, in all the 
cases, MCN has not had a significant effect. So, the anti- inflammatory and pro-regenerative effects of $\mathrm{MCN}+$ fisetin is mainly because of the fisetin.

One of the main results of an inflammatory reaction in a body is the over- production of pro-oxidative agents, like nitric oxide. In response to the increase in pro-oxidative radicals, the body attempts to maintain the oxidative balance, by producing more anti- oxidants, which can scavenge the harmful radicals. This leads to an increase in the proliferation of cells. This has been demonstrated clearly in our experiment, where treatment with TG has led to an increase in NO concentration. Due to the attack caused by TG, the body loses the battle to maintain the oxidative balance, and proliferation is reduced. The cells lose the ability to proliferate and form colonies on semi- solid medium. Fisetin is successful in restoring this balance to some extent. It successfully reduced the NO content, and increased the proliferation. It also increased the clonogenic potential of the cells, showing the cells have regained their ability to form colonies when given a matrix for growth. Fisetin, when loaded on MCN, has a similar effect to fisetin alone, but it does not have any additional effect, which we would want our nano-vehicle to have.

\section{Conclusion}

In conclusion, we demonstrated that fisetin and fisetin loaded on mesoporous carbon nanoparticle (MCN) may have anti-inflammatory effects on thioglycollate-induced peritonitis. To our knowledge, this is the first study to date to assess new therapeutic approaches using phytochemicals such as fisetin against peritonitis. Further studies are required to verify the clinical use of fisetin in the treatment of peritonitis, and also to determine the pathways by which it acts. The future research could focus on the combination of fisetin therapy and traditional antibiotics, which might be more efficient than using antibiotics alone. We can also investigate other nano- particles that can be used as vehicles, for better delivery of the drug.

\section{Contribution of Authors}

SM performed all experiments, analyzed data, SB gave valuable input to the manuscript, AS and NRJ have prepared the MCN, and ERB initiated the project with her idea, designed the experiments, analyzed all data and wrote the manuscript.

\section{Acknowledgement}

The authors wish to acknowledge UGC for providing fellowship and contingency grant to SM, Tata Education Trust for providing a stipend to SB and to WB DBT for providing a research grant to ERB, and SERB for funding the project of which ERB is the $\mathrm{PI}$, and provide funds for infrastructure development and necessary funds to undertake expenses related to the project. The authors also acknowledge Sattar Sekh and Manisha Murmu for technical help and Priyanka Dutta for her support for all purchase and accounts related activities critical for the smooth running of the project.

\section{References}

1. Anel RL, Kumar A (2001) Experimental and emerging therapies for sepsis and septic shock. Expert Opin Investig Drugs 10: 1471-1485.

2. Dellinger RP (2003) Inflammation and coagulation: implications for the septic patient. Clin Infect Dis 36: 1259-1265.

3. Ritter C, Andrades ME, Reinke A, Menna-Barreto S, Moreira JC, et al. (2004) Treatment with $\mathrm{N}$-acetylcysteine plus deferoxamine protects rats against oxidative stress and improves survival in sepsis. Crit Care Med 32: 342-349.

4. Baeuerle PA (1998) IkappaB-NF-kappaB structures: at the interface of inflammation control. Cell 95: 729-731.

5. Zingarelli B, Sheehan M, Wong HR (2003) Nuclear factor-kappaB as a therapeutic target in critical care medicine. Crit Care Med 31: S105-111.
6. Woltmann A, Hamann L, Ulmer AJ, Gerdes J, Bruch HP, et al. (1998) Molecular mechanisms of sepsis. Langenbecks Arch Surg 383: 2-10.

7. Hayden MS, Ghosh S (2004) Signaling to NF-kappaB. Genes Dev 18: 21952224

8. Liu SF, Malik AB (2006) NF-kappa B activation as a pathological mechanism of septic shock and inflammation. Am J Physiol Lung Cell Mol Physiol 290 L622-622L645.

9. Billing AG, Fröhlich D, Konecny G, Schildberg FW, Machleidt W, et al. (1994) Local serum application: restoration of sufficient host defense in human peritonitis. Eur J Clin Invest 24: 28-35.

10. Feng X, Liu J, Yu M, Zhu S, Xu J (2007) Protective roles of hydroxyethyl starch $130 / 0.4$ in intestinal inflammatory response and survival in rats challenged with polymicrobial sepsis. Clin Chim Acta 376: 60-67.

11. Ferrero-Miliani L, Nielsen OH, Andersen PS, Girardin SE (2007) Chronic inflammation: importance of NOD2 and NALP3 in interleukin-1beta generation. Clin Exp Immunol 147: 227-235.

12. Porth C (2007) Essentials of pathophysiology: concepts of altered health states. Hagerstown, MD: Lippincott Williams \& Wilkins.

13. Abbas AB, Lichtman AH (2009) Ch.2 Innate Immunity. In Saunders (Elsevier) Basic Immunology. Functions and disorders of the immune system ( $3^{\text {rd }}$ eds.).

14. Crunkhorn P, Meacock SC (1971) Mediators of the inflammation induced in the rat paw by carrageenin. $\mathrm{Br} \mathrm{J}$ Pharmacol 42: 392-402.

15. Cotran, Kumar, Collins (1998) Robbins Pathologic Basis of Disease. Philadelphia: W.B Saunders Company, USA.

16. Ulyanova T, Banerjee ER, Priestley GV, Scott LM, Papayannopoulou T (2007) Unique and redundant roles of alpha4 and beta2 integrins in kinetics of recruitment of lymphoid vs myeloid cell subsets to the inflamed peritoneum revealed by studies of genetically deficient mice. Exp hematol 8: 1256-1265.

17. Khan N, Syed DN, Ahmad N, Mukhtar H (2013) Fisetin: A dietary antioxidant for health promotion. Antioxid Redox Signal 19: 151-162.

18. Khan N, Adhami VM, Mukhtar H (2010) Apoptosis by dietary agents for prevention and treatment of prostate cancer. Endocr Relat Cancer 17: R39-52.

19. Khan N, Afaq F, Mukhtar H (2008) Cancer chemoprevention through dietary antioxidants: Progress and promise. Antioxid Redox Signal 10: 475-510.

20. Boisseau P, Loubaton B (2011) Nanomedicine, nanotechnology in medicine. Comptes Rendus Physique 12: 620

21. Kaur G, Narang RK, Rath G, Goyal AK (2012) Advances in pulmonary delivery of nanoparticles. Artif Cells Blood Substit Immobil Biotechnol 40: 75-96.

22. Mohamud R, Xiang SD, Selomulya C, Rolland JM, O'Hehir RE, et al. (2014 The effects of engineered nanoparticles on pulmonary immune homeostasis. Drug Metab Rev 46: 176-190.

23. Yin Fang, Dong Gu, Ying Zou, Zhangxiong Wu, Fuyou Li (2010) A LowConcentration Hydrothermal Synthesis of Biocompatible Ordered Mesoporous Carbon Nanospheres with Tunable and Uniform Size. Angew Chem Int Ed 49: 7987-7991.

24. Kim TW, Chung PW, Slowing II, Tsunoda M, Yeung ES, et al. (2008) Structurally ordered mesoporous carbon nanoparticles as transmembrane delivery vehicle in human cancer cells. Nano Lett 8: 3724-3727.

25. Shaobin W (2009) Ordered mesoporous materials for drug delivery Microporous Mesoporous Matter 117: 1-9.

26. Zhu J, Liao L, Bian X, Kong J, Yang P, et al. (2012) pH-controlled delivery of doxorubicin to cancer cells, based on small mesoporous carbon nanospheres. Small 8: 2715-2720.

27. Remick DG (2007) Pathophysiology of sepsis. Am J Pathol 170: 1435-1444

28. Fakhrudin N, Waltenberger B, Cabaravdic M, Atanasov AG, Malainer C, et al. (2014) Identification of plumericin as a potent new inhibitor of the NF-IB pathway with anti-inflammatory activity in vitro and in vivo. $\mathrm{Br} \mathrm{J}$ Pharmacol 171 1676-1686.

29. Ghiselli R, Giacometti A, Cirioni O, Mocchegiani F, Orlando F, et al. (2008) Efficacy of the bovine antimicrobial peptide indolicidin combined with piperacillin/tazobactam in experimental rat models of polymicrobial peritonitis. Crit Care Med 36: 240-245. 
Citation: Mitra S, Biswas S, Sinha A, Jana NR, Banerjee ER (2015) Therapeutic use of Fisetin and Fisetin Loaded on Mesoporous Carbon Nanoparticle (MCN) in Thioglycollate-induced Peritonitis. J Nanomed Nanotechnol 6: 332. doi:10.4172/2157-7439.1000332

Page 12 of 12

30. Davies MG, Hagen PO (1997) Systemic inflammatory response syndrome. Br J Surg 84: 920-935.

31. Tian J, Lin X, Guan R, Xu JG (2004) The effects of hydroxyethyl starch on lung capillary permeability in endotoxic rats and possible mechanisms. Anesth Analg 98: 768-774, table of contents.
32. Perkins ND (2000) The Rel/NF-kappa B family: Friend and foe. Trends Biochem Sci 25: 434-440.

33. Sha WC1 (1998) Regulation of immune responses by NF-kappa B/Rel transcription factor. J Exp Med 187: 143-146. 